Review

\title{
Fossil bivalves and the sclerochronological reawakening
}

\author{
David K. Moss* (D), Linda C. Ivany, and Douglas S. Jones
}

\begin{abstract}
The field of sclerochronology has long been known to paleobiologists. Yet, despite the central role of growth rate, age, and body size in questions related to macroevolution and evolutionary ecology, these types of studies and the data they produce have received only episodic attention from paleobiologists since the field's inception in the 1960s. It is time to reconsider their potential. Not only can sclerochronological data help to address long-standing questions in paleobiology, but they can also bring to light new questions that would otherwise have been impossible to address. For example, growth rate and life-span data, the very data afforded by chronological growth increments, are essential to answer questions related not only to heterochrony and hence evolutionary mechanisms, but also to body size and organism energetics across the Phanerozoic. While numerous fossil organisms have accretionary skeletons, bivalves offer perhaps one of the most tangible and intriguing pathways forward, because they exhibit clear, typically annual, growth increments and they include some of the longest-lived, non-colonial animals on the planet. In addition to their longevity, modern bivalves also show a latitudinal gradient of increasing life span and decreasing growth rate with latitude that might be related to the latitudinal diversity gradient. Is this a recently developed phenomenon or has it characterized much of the group's history? When and how did extreme longevity evolve in the Bivalvia? What insights can the growth increments of fossil bivalves provide about hypotheses for energetics through time? In spite of the relative ease with which the tools of sclerochronology can be applied to these questions, paleobiologists have been slow to adopt sclerochronological approaches. Here, we lay out an argument and the methods for a path forward in paleobiology that uses sclerochronology to answer some of our most pressing questions.
\end{abstract}

David K. Moss. Department of Environmental and Geosciences, Sam Houston State University, Huntsville, Texas 77431, U.S.A. E-mail: dxm112@shsu.edu

Linda C. Ivany. Department of Earth and Environmental Sciences, Syracuse University, Syracuse, New York 13244,U.S.A. E-mail: lcivany@syr.edu

Douglas S. Jones. Florida Museum of Natural History, University of Florida, Gainesville, Florida 32611, U.S.A. E-mail:dsjones@flmnh.ufl.edu

Accepted: 7 March 2021

*Corresponding author.

\section{Introduction}

Morphological change has long been the currency of studying evolutionary trends in the fossil record. A good deal of this change is likely brought about by some combination of changes in growth rate and/or life span (i.e., heterochrony), but for too long these data have been missing from paleobiology. Sclerochronology, the study of periodic features archived in skeletal portions of animals that grow by accretion, provides a tool with which to collect these data and offers the potential to dramatically expand our understanding of the evolution of life. For many organisms, the annual cycle of environmental variation is recorded in thickness patterns and/or geochemical variations in the growth increments of skeletal structures, providing a chronometer that allows for the calibration of life histories in time (e.g., Jones and Quitmyer 1996; Ivany 2012; Schöne and Surge 2012). These so called "paleontological clocks" (Pannella and MacClintock 1968) allow us to determine the age-at-size relationships crucial to a deeper understanding of morphologic change through ontogeny and within phylogenies.

Sclerochronology is not new, nor is it completely unknown to paleobiologists. The oftcited story of Leonardo da Vinci using external growth lines on bivalve shells to argue that the so-called figur'd stones found in the Italian

(C) The Author(s), 2021. Published by Cambridge University Press on behalf of The Paleontological Society. This is an Open Access article, distributed under the terms of the Creative Commons Attribution licence (http://creativecommons.org/ licenses/by/4.0/), which permits unrestricted re-use, distribution, and reproduction in any medium, provided the original work is properly cited. 
mountains were in fact the remains of ancient, once-living, marine organisms and did not belong in the mineral class may very well be one of the earliest examples of sclerochronology (Jones and Gould 1999). Unfortunately, it took almost five centuries for paleobiologists to pick up on the idea of using hard parts to tell time (though fisheries biologists started decades earlier; see, e.g., Belding 1910; Orton 1923; Weymouth 1923; Chamberlin 1931, 1933), and when they did, it was often applied to questions of geochronometry to refine constraints on astronomical cycles of the Phanerozoic (e.g., Wells 1963). But this appears to have largely been where the union of sclerochronology and paleobiology stopped. Even with the surge of studies on heterochrony in the 1970s (e.g., Gould 1977; Alberch et al. 1979) calling for constraints on life span and growth ratethe very data sclerochronology can providethe two fields remained disjointed. Jones and Gould (1999) showed the way forward when they used age-calibrated life histories to reveal the nuanced mechanisms of heterochrony in the oyster Gryphaea spp. from the Jurassic of the United Kingdom. Yet, despite some notable exceptions (e.g., Goodwin et al. 2008; Geary et al. 2012; Collins et al. 2016), the tools of sclerochronology never quite gained wide usage in the paleobiological realm.

More recently, questions of how metabolic rate might contribute to Phanerozoic trends in ecology and bioenergetics (Vermeij 1987; Bambach 1993; Finnegan et al. 2011; Clapham 2017) and body size (Finnegan et al. 2011; Heim et al. 2015; Pyenson and Vermeij 2016), perhaps as related to oxygen (Payne et al. 2011; Vermeij 2016), again showcase the value of information about growth rate and life span for fossil taxa. Frustratingly though, the connection between evolutionary and ecological processes and the tools that sclerochronology offers has yet to be fully realized. The result is that sclerochronology is often thought of as little more than a "handmaid" to the fields of geochronometry and paleoenvironmental reconstruction, just as paleontology was famously relegated in reference to the field of stratigraphy (though at the time, this was a compliment; e.g., Lapworth and Wilson 1871). Norman Newell opined that paleontology is far more than this, and in fact has much more to offer to evolutionary biologists than to geologists (quoted in Sepkoski 2012). So too do we here argue that sclerochronology has far more to offer than the admittedly useful, but perhaps theoretically uninspiring, service to fields that require such information for other reasons.

Insights provided by growth rate and life span can and will enrich the ways we look at the organisms and assemblages that make up the fossil record and give them new and different stories to tell. The fossil record is full of animals with skeletons that grow by accretion (e.g., mollusks, brachiopods, corals, vertebrates, and more). From our perspective though, fossil bivalves offer one of the most promising and intriguing paths forward. Bivalve growth increments are often visible even in the oldest of fossils (e.g., Runnegar 1974; Yancey and Ozaki 1986; Nützel et al. 2010), and in some cases preservation is even sufficient to retain original shell chemistry (Brand 1982; Seuß et al. 2009; Ivany and Runnegar 2010; Beard et al. 2015; Jimenez et al. 2019). Given that bivalves also exhibit an extreme range in life histories - from a matter of months (e.g., Donax variabilis; Jones et al. 2005) to more than 500 years (e.g., Arctica islandica; Butler et al. 2013) - they offer tremendous potential for novel insight. In this paper, we review the types of information and methodological approaches most relevant to paleobiological questions, articulate the value of sclerochronology to studies of evolution, and propose some exciting avenues of investigation explicitly related to the role of life histories in macroevolution and evolutionary ecology. Though we largely illustrate possibilities through the lens of bivalve life histories, all organisms with accretionary structures offer similar potential.

\section{Growth Increments, Time, and the "Right Kind" of Data}

Visual and chemical patterns accrued in accretionary skeletal hard parts give rise to the potential for a chronometer if growth can be calibrated to time. In bivalves, indicators of growth include commissure-parallel lines on the shell surface and dark/translucent bands in cross section, both produced by 


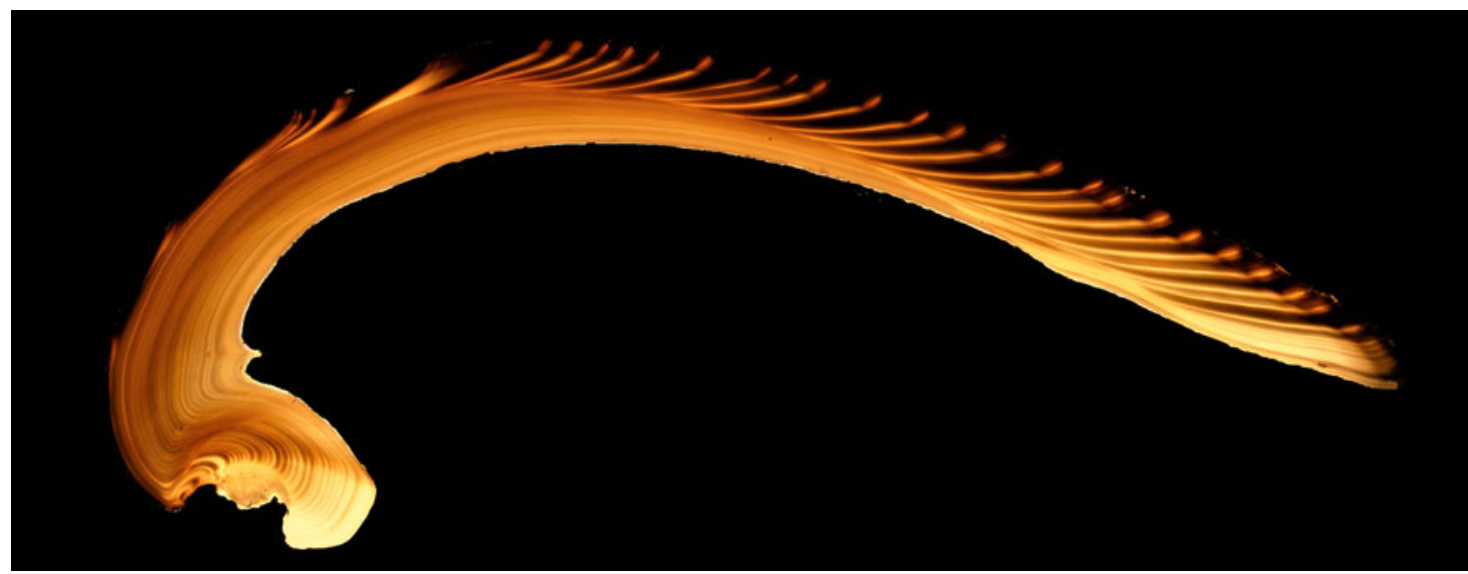

FIGURE 1. Backlit thin section of Mercenaria campechiensis (UF Z12524, University of Florida Museum of Natural History). Shell height $137.08 \mathrm{~mm}$; collected from Cedar Key, Florida, USA. Annual growth increments (translucent/bright in this view) are visible in hinge area and all shell layers.

changes in growth rate that change the proportion of organic matrix compounds (Lutz and Rhoads 1977) and/or the texture and regularity of crystal microstructure (Ropes et al. 1984) in the shell (Fig. 1). Shell growth bands and the increments they define (e.g., Jones 1980) are visible in both reflected and transmitted light and can be made more apparent with treatments such as acid etching (Ropes 1984) and staining with Mutvei's solution (Mutvei 1979; Schöne et al. 2005a).

Variation in the rate of accretion that produces bands and lines is driven by some combination of environmental, ecological, and physiological factors (Lutz and Rhoads 1980). Distinguishing the markers of annual growth, which allow for age determination, from the myriad of other potential lines indicating growth slowdowns or cessations on a range of timescales, both periodic and not (Pannella and MacClintock 1968; Clark 1974), is crucial to how sclerochronology can be applied to evolutionary questions related to growth and life span. Disturbance lines reflecting growth interruptions induced by storms, predation attempts, or abnormal environmental conditions (Clark 1974) can complicate the recognition of patterns with temporal significance, but these can often be distinguished from periodic lines by abrupt changes in microincrement widths that would otherwise decrease uniformly in advance of true annual increments
(Schöne and Surge 2012). Periodic lines in shells have been demonstrated to reflect at least five different frequencies: tidal, daily, fortnightly, monthly, and annual (e.g., Clark 1974; Pannella 1976; Richardson et al. 1980; Goodwin et al. 2001; Schöne et al. 2002, 2005b; Hallmann et al. 2008). Scales of environmental variation in the habitat determine which suite of periodic bands a shell will record. Some of these can be quite subtle and surprising (e.g., even deep-sea chemosymbiotic bivalves show tidal growth banding; Schöne and Giere 2005; Nedoncelle et al. 2015). Annual growth bands, most useful for age determination, are found in almost all modern bivalves outside the tropics and typically form in response to seasonal extremes in temperature (Jones and Quitmyer 1996), salinity (Richardson 2001), or food availability (Schöne et al. 2005b; Ballesta-Artero et al. 2017) and/or during spawning (Jones et al. 1983; Sato 1995). Winter growth cessations are common for species living above $25^{\circ} \mathrm{N}$ or $\mathrm{S}$ latitude, summer cessations tend to predominate between $15^{\circ}$ and $30^{\circ} \mathrm{N}$ or $\mathrm{S}$ latitude, and some species within $15^{\circ}$ of the equator record no cessations at all (Killam and Clapham 2018). Species that span a wide range of latitudes can form annual growth lines at different times of the year in different parts of their range. For example, Mercenaria mercenaria in the southern extent of its range forms lines in the summer, while in the north, annual lines 
reflect winter growth cessations (Jones et al. 1989; Quitmyer et al. 1997; Elliot et al. 2003).

Without independent temporal calibration, the assumption that growth bands are annual is not always a safe one (Jones 1981) - in some cases (e.g., many oysters; Surge et al. 2001; Tynan et al. 2014), visible growth increments bear no clear relation to intra-annual environmental variation. Geochemical variation along the axis of growth, however, often provides a means by which to confirm the timing of visible growth bands and reveal the annual cycle, thereby allowing calculation of growth rates and/or determination of ontogenetic age. Stable oxygen isotope values of shell carbonate are temperature dependent (Urey et al. 1951; Epstein et al. 1953; Grossman and $\mathrm{Ku}$ 1986) and therefore can track the seasonal temperature cycle experienced during an individual's lifetime, providing the chronometer for growth (Williams et al. 1982; Jones and Quitmyer 1996; Ivany 2012). Elemental ratios can also be useful for delimiting years, though the specific relationship to environment is often complicated by growth rate or other so-called vital effects (e.g., Gillikin et al. 2005; Poulain et al. 2015). A number of caveats exist regarding the use of ancient skeletal carbonate for paleotemperature determination, such as understanding the $\delta^{18} \mathrm{O}$ value of ancient seawater and confirmation of preservation of originial skeletal material (reviewed in Grossman 2012); nonetheless, this approach has been widely successful and broadly applied to questions of paleoclimate and seasonal variation. Some of these caveats are relaxed when the goal is simply the recognition of annual cycles rather than precise paleotemperature reconstructions, making stable isotope sclerochronology especially applicable to questions of life span, growth rate, and body size as distributed in time or space. Indeed, many of the studies referenced in this piece employ this approach to calibrating time in accretionary records.

\section{Quantifying Growth and Life Span}

Bivalves grow by accretion and have indeterminate growth. Counts and widths of annual growth increments provide an opportunity to collect quantitative, rather than qualitative, data on growth rates of ancient organisms over their lifetimes that can then be applied to evolutionary questions. A potential limitation to this kind of work is the need to section shells in order to reveal internal growth increments, which is not always possible in museum collections housing specimens from remote or no longer available localities. Making new collections expressly for this purpose obviates the problem, though in some cases this will not be possible. As a work-around, once the sizeage relationship is known from a few individuals, sizes of intact shells can be measured along that same axis (be it the axis of maximum growth or some other dimension consistently repeatable among individuals) to produce rough estimates of ontogenetic age for large numbers of individuals. Note, however, that this approach is not without complication (see "Investigating Life Span").

Promises and Pitfalls of the von Bertalanffy Growth Equation.-A number of equations have been used to describe bivalve shell growth, including various logarithmic and logistic equations (e.g., Jones et al. 1989; Sato 1994), but the von Bertalanffy growth equation (VBG; von Bertalanffy 1938) is the one most commonly applied to bivalves. The VBG fit to measurements of cumulative growth increment width from umbo to commissure yields statistically robust age-size relationships:

$$
L_{t}=L_{\infty}\left(1-e^{-k\left(t-t_{0}\right)}\right)
$$

where $L_{\mathrm{t}}$ is the length at some time, $L_{\infty}$ is the asymptotic height of the individual, $k$ is the rate at which $L_{\infty}$ is approached, and $t_{0}$ is the time at which $L_{t}=0$. This relationship states that the shell increases in size by adding successive annual increments that exponentially decrease in thickness with age, as measured perpendicular to the growth axis. Commercial fisheries have long used the VBG to approximate age-size relationships (e.g., Murawski et al. 1982). These relationships can then be used to establish age-length keys (ALKs) (Harding 2007; Pace et al. 2017) that, along with information on sexual maturity, are useful in properly maintaining sustainable population stock levels (Thorarinsdóttir and Jacobson 
2005). ALKs are perhaps best suited for shorterlived taxa, though, as the significant variation in age-at-size for most long-lived taxa creates much uncertainty in age assignment.

Though the VBG is the most common approach, it is not without limitation. First, $L_{\infty}$ can be thought of as the "maximum" size when the VBG is fit to data from a single individual. However, $L_{\infty}$ from an individual or group of individuals should not be used to estimate or predict the maximum body size for the taxon. When fitting age-size data from a population, the best-fit growth model will yield as many shells whose sizes fall above $L_{\infty}$ as shells that fall below it, because the best-fit line minimizes differences in expected and predicted values. While the mean VBG line might give a general description of growth for the taxon, it creates an issue when trying to predict the age of individuals from their sizes using the equation. To illustrate, the VBG equation can be solved algebraically for age:

$$
t=t_{0}-\frac{1}{k} * \ln \left(1-\left(\frac{L}{L_{\infty}}\right)\right.
$$

When $L>L_{\infty}$ the operation calls for taking the natural $\log$ of a negative number, which is mathematically invalid. Individuals larger than $L_{\infty}$ cannot be aged. This then calls into question the accuracy of ages determined for all other individuals using that equation. The VBG equation can therefore effectively describe growth in observed individuals or populations, but it is less useful for predicting age from size in unknown individuals.

Second, the VBG parameter $k$ is notoriously difficult to interpret and is often misquoted as a growth rate. However, the units of $k$ are $1 / \mathrm{yr}$, and it cannot and should not be used as an explicit growth rate. Rather, $k$ can be thought of as the constant in an exponential decay function similar to those used in radiometric dating approaches, where $y=a e^{b x}$. The von Bertalanffy constant $\mathrm{k}$ then becomes the rate-of-decay term $b$. When considering individuals and/or populations with similar $L_{\infty}$ values, those with higher $k$ values will approach maximum sizes faster, because the rate of decay of growth increment thickness $(k)$ is higher than that for individuals with lower $k$ values.

Comparing Growth Rates.-For the paleontologist, especially one studying heterochrony or energetics through time, a metric with which to compare growth rates of individuals is of significant importance. The VBG parameter $k$ has been suggested by us (Moss et al. 2016, 2017) and others to be a suitable proxy for growth rate, but as discussed earlier, this can be problematic. A better approach, especially when comparing populations in both space and time or across taxa, might be to use the $\omega$ parameter derived by Gallucci and Quinn (1979), as it standardizes for body size:

$$
\omega=k * L_{\infty}
$$

This reparameterization of VBG offers a way to test hypotheses of difference in growth rates between populations, because it compares the growth of individuals near $t_{0}$ and is in units of length/time. The $\omega$ parameter also avoids issues of the negative correlation between $k$ and $L_{\infty}$ within individuals from a population (Gallucci and Quinn 1979).

To illustrate this concept, consider age-at-size data collected from the Atlantic surf clam, Spisula solidissima, previously published by one of us (Jones et al. 1978; Ambrose et al. 1980). These data represent populations from an inshore and an offshore setting off the coast of New Jersey, USA, and they are an often-cited example of potential environmental controls on longevity and growth rate. The traditional approach to resolving differences in life-history strategy between the two populations is to fit a mean VBG growth curve to size-at-age data from each population. Visual inspection of the data reveals that individuals from the inshore population tend to be smaller and shorter lived than those from the offshore population (Fig. 2). VBG parameters for the equations best fit to the data from each of the populations demonstrate that the inshore population has a lower $L_{\infty}(84.75$ vs. $121.58 \mathrm{~mm})$ and a higher $k$ value $(0.29$ vs. 0.24$)$ compared with the offshore population. In other words, while inshore individuals do not live as long or grow as large as offshore individuals, they approach their asymptotic sizes faster. Treating $k$ (erroneously) 


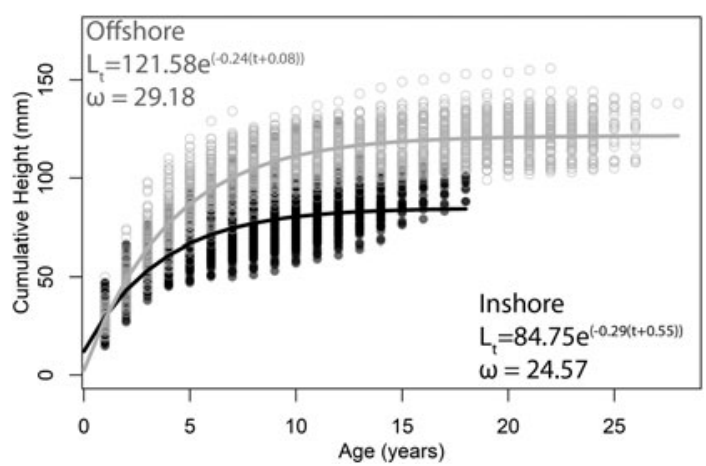

FIGURE 2. Best-fit von Bertalanffy growth equations to size-at-age data of Spisula solidissima from New Jersey. Filled circles are from "inshore" individuals $(k=0.29)$; open circles are from "offshore" individuals $(k=0.24)$. Data are from Jones et al. (1978) and Ambrose et al. (1980).

as a direct measure of growth rate, we might conclude that inshore individuals grow faster than offshore individuals. However, this is not the case. At any given age, the height of offshore clams is greater than those of inshore clams. Hence, in terms of shell accreted per year, offshore clams are growing faster than inshore clams despite having lower $k$ values. Calculating $\omega$ from the two best-fit VBG equations, however, reveals the intuitive difference between the two populations illustrated in the growth curves (inshore $=24.57$; offshore $=$ 29.18; Fig. 2). The $\omega$ parameter therefore reveals itself to be a better metric for comparing growth between populations, especially when their individuals reach different sizes.

Using a single curve to describe the growth of an entire population is somewhat unsatisfying given the time and effort required to obtain such a large dataset. In the $S$. solidissima example, data on size-at-age for 412 sectioned counted and measured bivalves - a total of 5614 data points (3110 for inshore, 2504 for offshore) - have been reduced to two best-fit lines. Such an approach, while potentially illustrative of a broad general pattern, does not allow for an understanding of the variation in growth parameters among individuals that a population encompasses. Fitting VBG equations and deriving growth parameters for each individual in the dataset allows for a more sophisticated statistical comparison of their means and ranges of variation (Fig. 3). As expected from the growth curves, $L_{\infty}$ is higher for offshore individuals, but $k$ values overlap almost entirely. Values of $\omega$ for offshore individuals, however, are significantly higher than those for the inshore individuals, reflecting faster growth early in ontogeny.

Investigating Life Span.-Increment data, VBG parameters, and $\omega$ are effective ways to assess and compare growth trajectories among sampled individuals. There are occasions, however, when life span itself is the variable of interest and assessing life span comes with its own set of issues with respect to both detecting annual increments and reliably estimating age from body size.

In cases in which all growth bands are clearly visible and known to be annual, establishing life span is trivial. However, because linear accretion rate decreases throughout ontogeny, very little shell material may be added to the growing margin each year later in life (e.g., $<0.1 \mathrm{~mm}$ in long-lived species like Arctica islandica; Thorarinsdóttir and Jacobson 2005). In some species, particularly those that are long lived and/or slow growing, growth increments become too compressed and obscured near the commissure to allow for accurate counting and measuring. In these instances, the hinge region often records a clearer record of growth increments, perhaps because the hinge is protected from environmental disturbances experienced at the commissure that might disrupt accretion. We find this to be the case, for example, for Glycymeris and Arctica (Thompson et al. 1980), as have others working both in the fossil record (Johnson et al. 2019) and with modern bivalves (Peharda et al. 2012, 2016; Brocas et al. 2013; Reynolds et al. 2013a; Mette et al. 2016). In such cases we suggest transforming the data to represent shell height as would be measured using a standard pair of calipers (i.e., the "straight line" dorsal to ventral distance), accomplished by dividing the measured increment width by the total length of the hinge, then multiplying by the shell height. Doing so allows growth curves to be investigated in the context of the overall measured size distribution of a population.

The vagaries of preservation and limits on the choice or number of shells that can be sectioned and counted can put researchers in the 

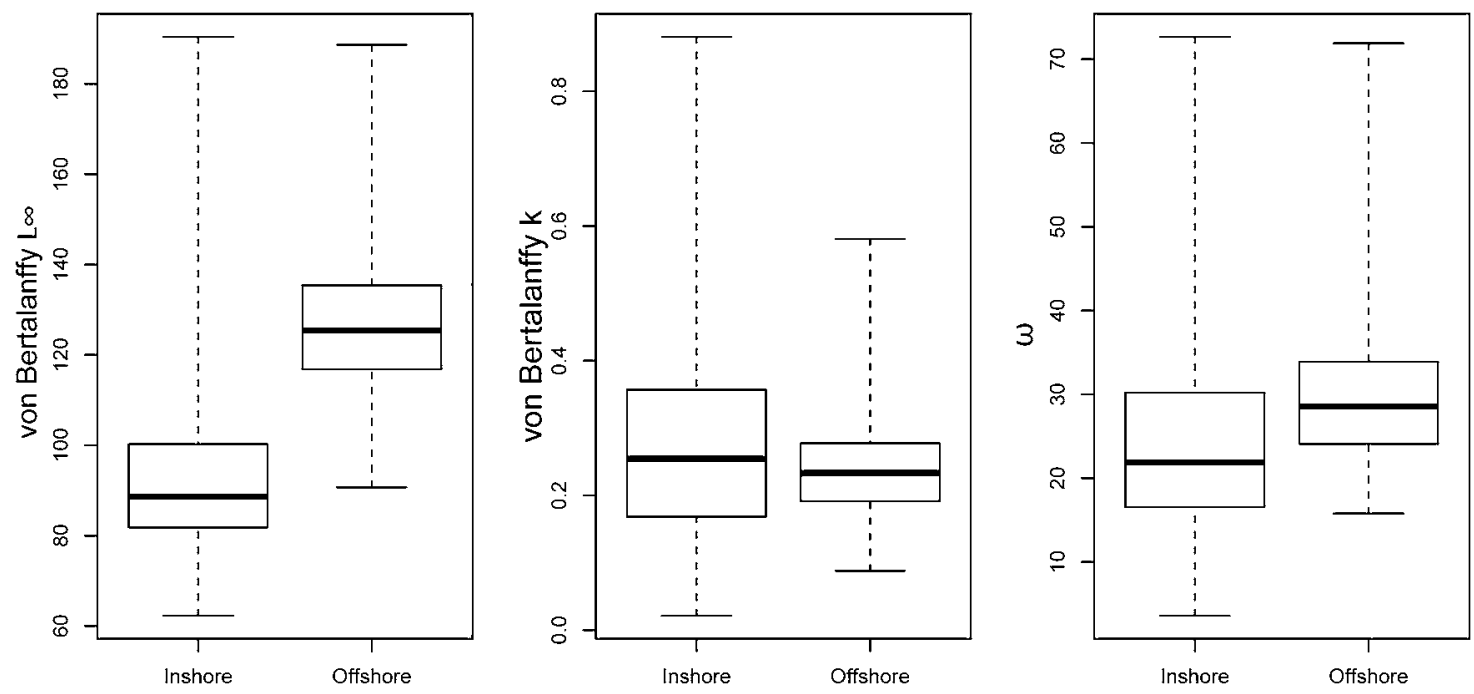

FIGURE 3. Box plots of von Bertalanffy and $\omega$ parameters for each individual in Fig. 2. Boxes outline the inter quartile range. Whiskers extend to the extremes.

position of needing to estimate life span from body size alone, using growth curves either from those same individuals that are incomplete or obscured (e.g., Buick and Ivany 2004) or from a subset of other individuals in that population or taxon. Cumulative shell height yields a body size measure that is clearly related to age, but real variation in the shape and rate of growth of individuals within a species, together with methodologically imposed variation due to inconsistencies in the axis along which shells are cut and/or measured, gives rise to differences in overall distance along the measured axis of growth that are not related to age (e.g., the variance in Fig. 2). This makes predictions about the age of individuals based on their body size alone more tenuous.

ALKs originally developed for modern fisheries (Fridriksson 1934) take this approach and are often applied to modern shellfish (e.g., Harding 2007; Pace et al. 2017). ALKs are constructed by first determining the size and age of a subset of a population. From this subset, the proportion of different ages in each length group (usually $5 \mathrm{~mm}$ categories) is determined and then used to assign ages to all individuals in the unknown sample (Kimura 1977; Bartoo and Parker 1983; Bettoli and Miranda 2001). Despite their widespread and generally successful use in fast-growing modern populations, ALKs rely on a large number of initial samples to characterize the age-size relationships of an entire population, which does not avoid the issue of destructive sampling so often a concern for fossil specimens. As well, the approach is still subject to the problem outlined earlier - if there is significant overlap in size among age groups, as is typical for bivalves (see Fig. 2), ALKs tend to yield unreliable results (Westerheim and Ricker 1978). For shorter-lived, fast-growing taxa, errors tend to be small. But for long-lived taxa, differences in size of only a few millimeters later in life could equate to differences in estimated age of decades. The vagaries that affect growth in the first few years of life, when shells are typically growing faster, can result in large differences in body size among individuals of the same age later in life, effectively making age estimates from body size alone in in long-lived taxa impossible. Finally, the range of sizes for which age can be approximated using an ALK is determined by the original subsample. This means that an individual larger than any length category in the subsample either cannot be assigned an age or is erroneously assigned the age of the largest subsampled specimen. New probabilistic approaches to reasonably estimate age from 
size in long-lived taxa are sorely needed if life span is to be more widely investigated in the fossil record.

\section{The Reawakening}

Despite persistent methodological frustrations, the study of life-history evolution allowed by the combination of life-span and growth rate data archived in the shells of marine bivalves poses intriguing possibilities for macroevolution and ecology in deep time. Bivalves appear in the fossil record in the Early Cambrian (e.g., Jell 1980; Runnegar and Bentley 1983) and dominate shallow-marine settings from the Mesozoic to the present (e.g., Gould and Calloway 1980; Liow et al 2015; Hsieh et al. 2019). Their preservation potential is high even in deep time (e.g., Jimenez et al. 2019). They are therefore capable of recording very long-term patterns in the evolution of life histories. In the following sections, we offer some potential directions for future exploration.

Extreme Longevity.-We have been interested in the evolution of extreme longevity and the mechanism(s) by which it is brought about for some time (Jones 1980, 1983; Buick and Ivany 2004; Moss et al. 2017). While the modal maximum age of a bivalve today is 3 years (Moss et al. 2016), more than 30 species are known to attain life spans in excess of 50 or even 100 years (Table 1 ). So-called maximum life span is inherently difficult to assess, as every specimen analyzed comes with the potential to extend the documented life span of a taxon. Nevertheless, the unusual set of ecological and life-history characteristics associated with species that can live for centuries is intriguing and invites further study. Is extreme longevity an ecophenotypic side consequence of slow metabolism due to thermal or caloric constraints, or has longevity been selected for through higher life span-integrated fecundity or some other advantage it confers under certain circumstances (see discussions in Buick and Ivany 2004; Philipp and Abele 2010; Moss et al. 2017)? Are the known examples simply derived, circumstance-specific curiosities, or might they be relics from the deep past? Does, and how does, the distribution of life spans change over the course of the Phanerozoic? If greater longevity in bivalves is associated with slower growth (Abele et al. 2009; Ridgway et al. 2011a; Moss et al. 2016), predictions arise from fundamental macroevolutionary and ecological trends postulated by paleobiologists. For example, if metabolic activity on average increases over the Phanerozoic, as suggested by Bambach (1993), longevity and von Bertalanffy $k$ and $\omega$ values should change systematically too. Likewise, predictions arise from the postulated impacts of escalation (sensu Vermeij 1987) over time. High predation pressure could select for early growth to size refugia that prevent drilling or shell crushing. Alternatively, low or almost nonexistent predation could accommodate extremely slow growth and low metabolic rate, thereby promoting longevity. Documented low predation pressure (Aronson et al. 1997; Harper et al. 2018) might contribute to the presence of multiple unrelated long-lived taxa in the Cretaceous and Paleogene highlatitude deposits on Seymour Island, Antarctica (Moss et al. 2017). If true, one might predict that slow growth and long life were not as unusual in the deep past as they are now. We expand on these questions a bit more in "BodySize Evolution and Energetics." Despite an available tool kit for assessing life history, few studies have explicitly examined the life spans of fossil species in these contexts.

Phylogenetic Expression.-Sclerochronologically derived growth rates and longevities combined with phylogenetic comparative methods can inform us about how life-history traits map across the bivalve tree through time. Despite perceptions of a wealth of information, available life-history data for bivalves are concentrated within three subclasses (Moss et al. 2016): Heterodonta $(n=193)$, Pteriomorphia $(n=89)$, and Protobranchia $(n=15)$ (Fig. 4). Limited taxonomic coverage might therefore restrict the potential questions-or at least their scope - that can be asked for the time being, and much work is needed to answer questions about the inheritance of life-history traits. However, the presence of centenarian taxa in all three subclasses suggests that extreme longevity has come about 
TABLE 1. Life spans of modern bivalves known to attain life spans $>50$ years. Updated from Moss et al. (2016). MLSP, maximum reported life span for that species. See references for locality information.

\begin{tabular}{|c|c|c|c|}
\hline Family & Species & MLSP & Reference \\
\hline Arcticidae & Arctica islandica & 507 & Butler et al. 2013 \\
\hline Astartidae & Astarte borealis & 150 & Torres et al. 2011 \\
\hline Cardiidae & $\begin{array}{l}\text { Tridacna crocea } \\
\text { Tridacna gigas }\end{array}$ & $\begin{array}{l}60 \\
60\end{array}$ & $\begin{array}{l}\text { Hamner and Jones } 1976 \\
\text { Pearson and Munro } 1991\end{array}$ \\
\hline Glossidae & Glossus humanus & 78 & Reynolds et al. 2013a \\
\hline Glycymerididae & $\begin{array}{l}\text { Glycymeris bimaculata } \\
\text { Glycymeris longior } \\
\text { Glycymeris pilosa } \\
\text { Glycymeris glycymeris }\end{array}$ & $\begin{array}{r}57 \\
69 \\
72 \\
192\end{array}$ & $\begin{array}{l}\text { Bušelić et al. } 2015 \\
\text { Gimenez et al. } 2020 \\
\text { Peharda et al. } 2018 \\
\text { Reynolds et al. } 2013 \mathrm{~b}\end{array}$ \\
\hline Hiatellidae & $\begin{array}{l}\text { Panopea globosa } \\
\text { Panopea zelandica } \\
\text { Panopea abbreviata } \\
\text { Cyrtodaria siliqua } \\
\text { Hiatella arctica } \\
\text { Panopea generosa }\end{array}$ & $\begin{array}{r}60 \\
85 \\
86 \\
105 \\
126 \\
168\end{array}$ & $\begin{array}{l}\text { Aragón-Noriega et al. } 2015 \\
\text { Gribben and Creese } 2005 \\
\text { Morsan et al. } 2010 \\
\text { Kilada et al. } 2009 \\
\text { Sejr et al. } 2002 \\
\text { Bureau et al. } 2002\end{array}$ \\
\hline Mactridae & $\begin{array}{l}\text { Spisula voyi } \\
\text { Mactromeris polynyma } \\
\text { Spisula sachalinensis }\end{array}$ & $\begin{array}{l}52 \\
60 \\
70\end{array}$ & $\begin{array}{l}\text { Yavnov and Ignat'ev } 1979 \\
\text { Cassista and Hart } 2007 \\
\text { Selin } 1990\end{array}$ \\
\hline Myidae & Mya truncata & 50 & Sejr and Christensen 2007 \\
\hline Mytilidae & $\begin{array}{l}\text { Lithophaga lithophaga } \\
\text { Bathymodiolus childressi } \\
\text { Crenomytilus grayanus }\end{array}$ & $\begin{array}{r}54 \\
100 \\
150\end{array}$ & $\begin{array}{l}\text { Galinous-Mitsoudi and Sinis } 1995 \\
\text { Smith et al. } 2000 \\
\text { Zolotarev } 1980\end{array}$ \\
\hline Nuculidae & Ennucula tenuis & 60 & Torres et al. 2011 \\
\hline Tindariidae & Tindaria callistiformis & 100 & Turekian et al. 1975 \\
\hline Ungulinidae & Diplodon chilensis patagonicus & 90 & Soldati et al. 2009 \\
\hline Veneridae & $\begin{array}{l}\text { Ezocallista brevisiphonata } \\
\text { Tivela stultorum } \\
\text { Eurhomalea exalbida } \\
\text { Mercenaria stimpsoni } \\
\text { Mercenaria mercenaria }\end{array}$ & $\begin{array}{r}52 \\
53 \\
70 \\
99 \\
106\end{array}$ & $\begin{array}{l}\text { Selin and Selin } 1988 \\
\text { Gillilan } 1964 \\
\text { Lomovasky et al. } 2002 \\
\text { Tanabe et al. } 2017 \\
\text { Ridgway et al. } 2011 \mathrm{~b}\end{array}$ \\
\hline Yoldiidae & $\begin{array}{l}\text { Portlandia arctica } \\
\text { Aequiyoldia eightsi }\end{array}$ & $\begin{array}{l}55 \\
65\end{array}$ & $\begin{array}{l}\text { Torres et al. } 2011 \\
\text { Peck and Bullough } 1993\end{array}$ \\
\hline
\end{tabular}

independently on multiple occasions and likely characterized the age frequencies of early bivalve groups as well. The degree to which age distributions have shifted over the course of the Phanerozoic is an outstanding question with important implications, as discussed further later. Little has been done to investigate potential relationships, but an analysis by Saulsbury et al. (2019) suggests that life span and von Bertalanffy $k$ are conserved within lineages of bivalves. If life span is a taxonspecific trait, it strengthens the argument for genetic control of life history and opens the door for longevity or its correlates (e.g., growth rate) to have bearing on the origin and differential survival of species. Indeed, some authors have begun to make this argument for bivalves in the context of extreme longevity (Abele and Philipp 2013).

Because the tools of sclerochronology have only been sparingly applied to life histories of fossil bivalves, a bottom-up approach is necessary to begin answering questions of phylogenetic expression in deep time. The study of 


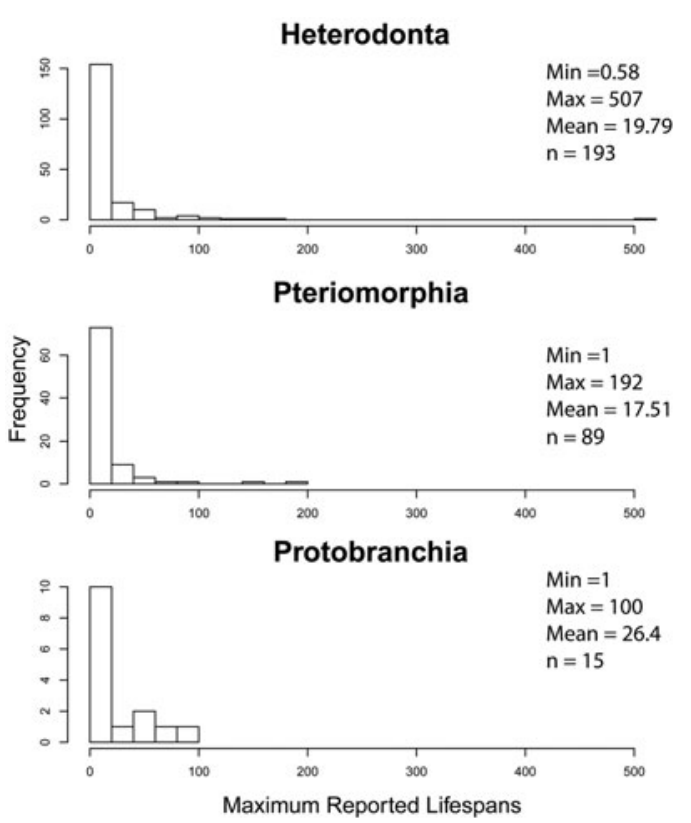

FIGURE 4. Histograms of maximum reported life spans for bivalve subclasses, updated from Moss et al. (2016).

ancient bivalve life histories is in such infancy that almost any data generated for fossil taxa are likely to generate novel hypotheses. A worthwhile effort would be to assemble phylogenies for taxa that show, for example, long life spans today, push them back in time using the rock record, and try to discern patterns in the heritability of life-history traits within genera, eventually working toward higher taxonomic levels. Several phylogenies already exist that can facilitate this effort (e.g., Anderson and Roopnarine 2003; Goodwin et al. 2008; Bieler et al. 2014; McClure and Lockwood 2015; Collins et al. 2016; Alvarez and del Rio 2020). These analyses would have to be done in the context of climate, as temperature also plays a role in setting life-history traits, but the stable oxygen isotope data generated to verify the annual nature of growth increments can also yield that information. We illustrate two pathways for futher exploration of phylogenetic control, but of course many similar opportunities exist across the Bivalvia.

The life-history traits of the cool-water bivalve Arctica islandica appear to be taxon specific and hence likely genetically controlled. As the longest-lived non-colonial animal on the planet, $A$. islandica has garnered much attention from the medical community studying the aging process (Philipp and Abele 2010). In one study (Ungvari et al. 2013), A. islandica was found to have a higher capacity to resist the oxidative stressors commonly associated with aging than two shorter-lived species (Mercenaria mercenaria: maximum reported life span $[\mathrm{MLSP}]=100$ years; Argopecten irradians irradians: $\mathrm{MLSP}=2$ years). Other studies have confirmed the same using alternative approaches, and it seems that $A$. islandica might trade slow growth and late onset of reproduction for lower rates of cell damage (e.g., Strahl et al. 2007).While its maximum life span of 507 years is reported from near the northernmost extent of its range, in Iceland (Butler et al. 2013), it routinely reaches ages in excess of 200 years off the U.S. coastline (e.g., Ropes 1984; Fritz 1991), and its von Bertalanffy $k$ values throughout its distribution are consistently some of the lowest reported of any bivalve (Moss et al. 2016). Are the extreme longevity and slow growth of modern $A$. islandica recently acquired, or inherited from an earlier member of the lineage? Pleistocene representatives exhibit life spans exceeding several centuries in midlatitude settings (von Leesen et al. 2017), suggesting that extreme longevity has been a trait of $A$. islandica throughout time. While monotypic today, the genus appears to have originated during the Triassic (Giebel 1856), affording the opportunity to study the evolution of life-history traits over a long stretch of geologic time. We are aware of life-history data from only one other member of the genus, Arctica ovata, albeit from a small sample $(n=3)$. Nevertheless, during the greenhouse conditions of the Cretaceous, A. ovata lived for at least two decades in the northern part of the Western Interior Seaway (Jones 1988). If the data were available, how would life span distribute across a phylogeny for the genus as a whole in comparison to its ancestor or sister groups?

While Arctica certainly presents an interesting avenue for exploration in deep time, not all bivalves are created equal, and some groups will lend themselves better to understanding the phylogenetic expression of longevity than others. When deciding how to proceed in this 


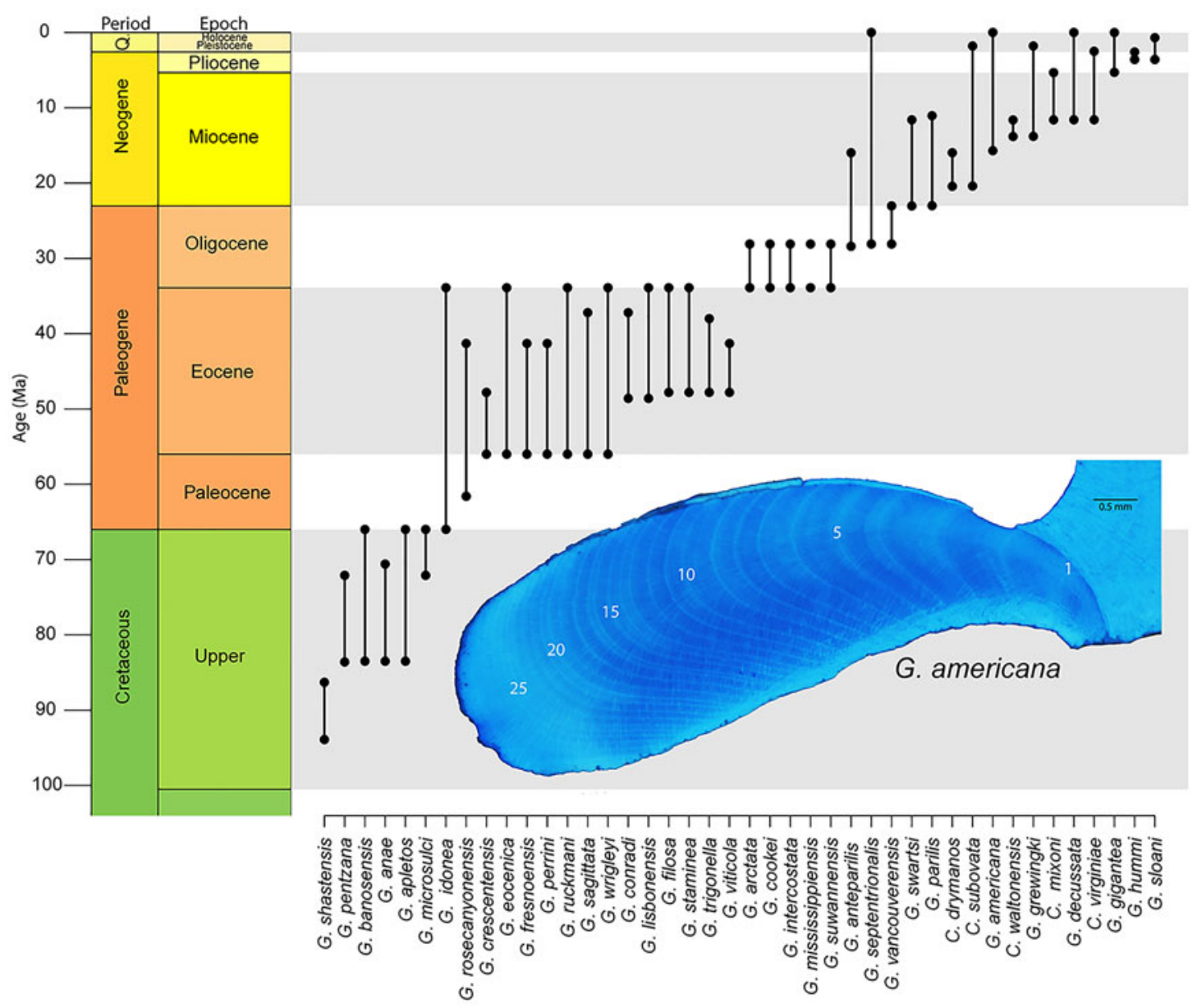

FIGURE 5. Stratigraphic ranges for Glycymeris from North America as reported in the Paleobiology Database. Ranges for species of Costaglycymeris are also included, as they are likely closely related to Glycymeris. Insert shows hinge region growth increments of G. americana stained with Mutvei's solution. Specimen is from Pleistocene, Waccamaw Formation in North Carolina, USA.

direction, efforts are perhaps best focused on groups that have: (1) modern phylogenies that can help guide hypotheses; (2) robust shell material that would increase the potential for growth increment preservation; and (3) a considerable amount of life-history data from modern representatives, including long-lived taxa. One such group is the order Arcoida. Recently published molecular phylogenies have begun to unravel the complex relationships within the group (Oliver and Holmes 2006; Feng et al. 2015; Combosch and Giribet 2016; Kong et al. 2020), including the nesting of the Cucullaeidae and Glycymerididae. Our work (Moss et al. 2017) and that of others (e.g., Walliser et al. 2015; Johnson et al. 2019) have shown fossil representatives of these superfamilies to include long-lived species. Modern Glycymeris might be the most approachable, as representatives are known for their easily readable growth increments and impressive longevity (see Table 1) and could provide a genetic basis from which to build a more focused phylogeny. The genus originates in the Mesozoic and is well preserved in the Cenozoic sediments of eastern North America and Europe (Fig. 5), so a study spanning an entire ocean basin is conceivable. A phylogeny, albeit pre-cladistics revolution, for Plio-Pleistocene Glycymeris from the Atlantic Coastal Plain of the United States (Thomas 1970) can serve as the foundation for such a study. 
Latitudinal Life-History Gradient (LLHG).The spatial distribution of life spans and growth rates among bivalves today is distinctly nonrandom. Despite a good deal of variation, modern marine-shelf Bivalvia display a statistically significant LLHG of increasing life span and decreasing von Bertalanffy $k$ values moving from the tropics to the poles (Moss et al. 2016). At the high latitudes, variance in life span is high, but growth is universally slow; in the tropics, $k$ is variable, but life span is universally short, aside from photosymbiotic taxa. This general pattern holds within orders and within at least 12 well-sampled species (Moss et al. 2016). The freshwater bivalve Margaritifera displays a similar pattern (Bauer 1992).

Such a trend with latitude calls for an explanation based on factors linked with latitude, such as temperature, light regime, and/or predation pressure. Cooler temperatures (Brey and Clarke 1993; Clarke et al. 1993; Peck and Conway 2000) and restricted availability of food (Masoro 2000) have often been suggested to promote longer life spans through a reduction in metabolic rate (e.g., Basova et al. 2012). Thus, the modern LLHG might be driven by some combination of cooler temperatures and the highly seasonal light regime and associated seasonal abundance (and dearth) of phytoplankton at the poles. Saulsbury et al. (2019) find that winter temperature explains more of the variance in the von Bertalanffy growth coefficients of modern bivalves than does summer temperature or productivity, but not surprisingly, the situation is complex (Reed et al. 2020) and the variance, high. The presence of several species of long-lived bivalves in the Cretaceous and Paleogene of Antarctica (Buick and Ivany 2004; Ivany et al. 2011; Moss et al. 2017; Fig. 6A-C), when nearshore water temperatures approached those along the modern mid-Atlantic Coast, USA (Douglas et al. 2014; Tobin et al. 2014; Petersen et al. 2016; Judd et al. 2019), suggests that something about high-latitude settings beyond temperature alone is facilitating extreme longevity. Nevertheless, the LLHG predicts that the high latitudes should harbor a greater proportion of long-lived taxa back through time as well, and perhaps particularly so during times of icehouse conditions. At least two moderately long-lived bivalves are known from the early Permian glacially influenced settings of SE Australia (Fig. 6D,E): Eurydesma cordatum likely attained life spans in excess of 30 years (Ivany and Runnegar 2010; Beard et al. 2015), and Myonia corrugata lived for at least 55 years (Ivany and Runnegar 2007), but data thus far are few.

To the degree that temperature is a predictor of life history, as global temperature gradients decrease with overall warming, so too should the slope and strength of the LLHG in marine bivalves. We currently know very little about how the LLHG of marine bivalves changes with global climate change over the Phanerozoic. However, a recent study by Palmer et al. (2021) suggests that the latitudinal gradient in VBG $k$ for Mercenaria spp. might be steeper in the cooler Pleistocene than during the midPliocene warm period, as might be hypothesized given evidence for polar amplification (warming) during the Pliocene (Lunt et al. 2012; Hopcroft et al. 2020). A broader study of the mid-Pliocene fauna is required to test the hypothesis of a shallower gradient for the Bivalvia during this warm interval, but such a project is within reach given the extensive and fossil-rich deposits of the coastal plain. Furthermore, the presence of the aforementioned high austral taxa is suggestive of the persistence of a gradient during both warm, equable greenhouse intervals and cool, seasonal icehouse intervals, but currently there are insufficient low-latitude data with which to compare them to assess a possible change in slope. Another potentially fruitful study area is the Cretaceous Western Interior Seaway of North America, containing a well-sampled bivalve fauna stretching from the Gulf of Mexico into northern Canada. Interestingly, though only anecdotal thus far, Erickson and Palmateer (1996) describe Panopea in a latest Cretaceous assemblage from North Dakota (paleolatitude $\sim 50^{\circ} \mathrm{N}$ ) and report a maximum of only 16 growth bands in specimens as large as $91 \mathrm{~mm}$ in length. Today at that latitude, Panopea averages more than 100 years old (Bureau et al. 2002; Moss et al. 2016).

Life-History Evolution and the Latitudinal Diversity Gradient (LDG).--The degree to 


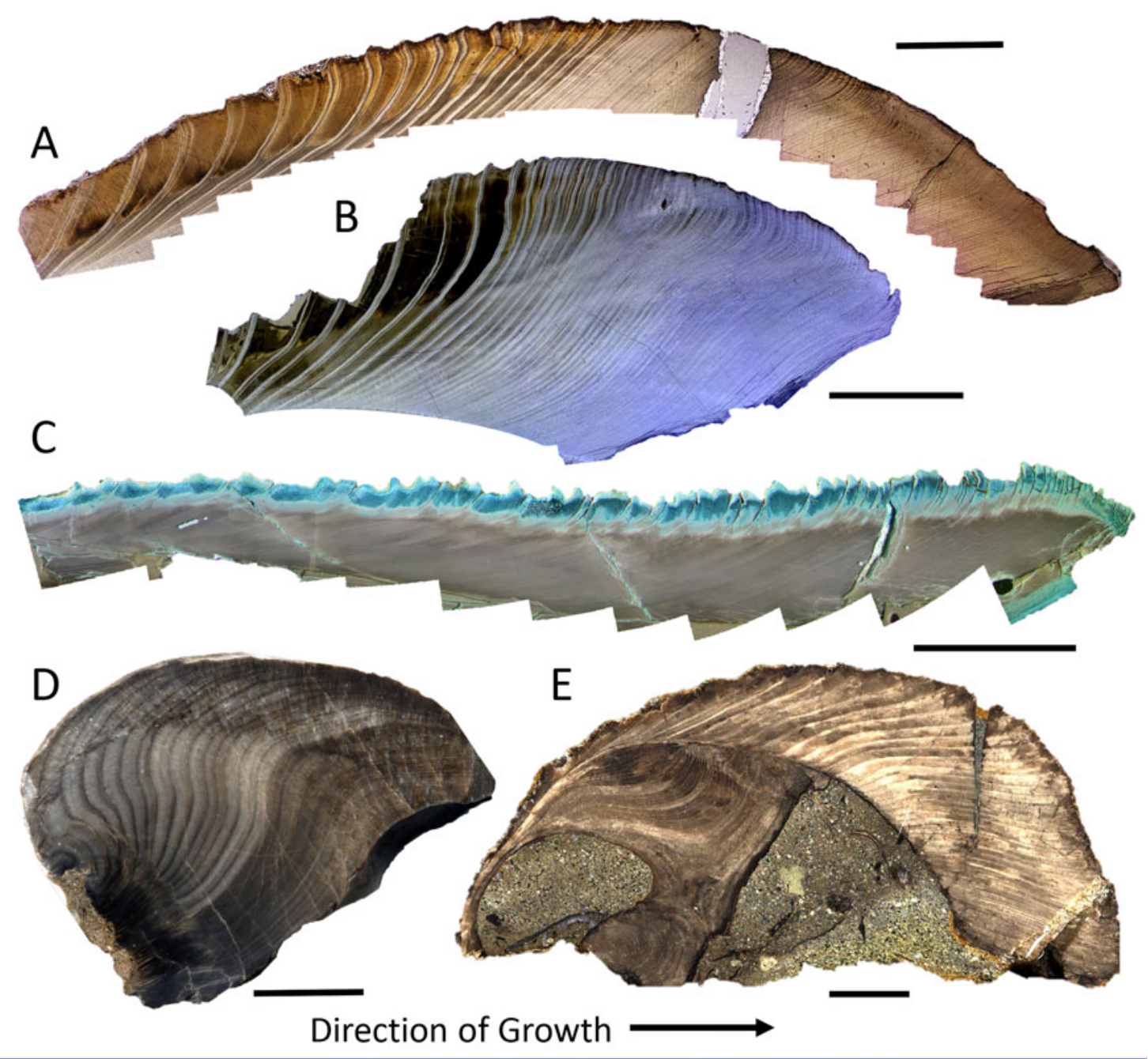

FIGURE 6. Annual growth banding in a sample of long-lived, high-latitude, fossil bivalves, showing partial or complete ontogenetic sequences. Cucullaea raea (A, B) and Retrotapes antarctica (C) (with Mutvei's stain) from the middle Eocene of Seymour Island, Antarctica. Images depict only the middle and outer shell layers (A, C), and growing margin of the shell (B). The umbonal region of Eurydesma cordatum (D) and complete shell of Myonia corrugata (E) from the early and late Permian, respectively, of the South Sydney Basin, Australia. Both localities have paleolatitudes of about $70^{\circ} \mathrm{S}$. Growth is from left to right in each case. Scale bars for A-C $0.5 \mathrm{~cm}$; scale bars for D and E, $1 \mathrm{~cm}$. Annual nature of banding in these taxa is documented in Buick and Ivany (2004); Ivany and Runnegar (2007, 2010); Ivany et al. (2008); Beard et al. (2015); Moss et al. (2017); Judd et al. (2019).

which the LLHG characterizes life histories in deep time raises several questions for evolutionary paleobiology. From a macroevolutionary perspective, if the LLHG holds in the past, it could contribute to the most evident pattern in biodiversity on the planet's surface today, the LDG (Moss et al. 2016). Modern bivalves follow a robust LDG (Crame 2000, 2002; Roy et al. 2000; Valentine and Jablonski 2010; Jablonski et al. 2017) that results from some combination of higher speciation rates in and range expansion beyond the tropics (Crame 2000; Jablonski et al. 2006, 2013, 2017; Clarke and Crame 2010). The reasons behind higher origination rates in the tropics are poorly understood (Jablonski et al. 2006), but life history could play a role. As related before, tropical bivalves tend to have higher $k$ values than mid- and high-latitude bivalves (Moss et al. 2016). Higher von Bertalanffy $k$ values 
represent a "faster" approach to the asymptotic size $\left(L_{\infty}\right)$, and body size positively correlates with reproductive potential in bivalves (e.g., Peterson 1986; Nakaoka 1994). Tropical bivalves then, with their typically higher $k$ values, would likely reach reproductive maturity faster and hence have shorter generation times. These latter traits are correlated with faster rates of molecular evolution in invertebrates (e.g., Thomas et al. 2010) and mammals (Nabholz et al. 2008). Faster growth and shorter generation times in the tropics might therefore drive the LDG at least in part because of the greater potential to accumulate mutations upon which selection can then act. Conversely, polar taxa have lower $k$ values and slower growth and tend to delay the onset of sexual maturity (Ridgway et al. 2011a), all of which might make them less likely to generate new taxa. This does not address the component of range expansion out of the tropics, but the propensity for higher tropical origination rates could well be traced back to life-history parameters.

If the LLHG is related to the LDG today, then this might be the case in the past as well. An LDG has been demonstrated for a number of time intervals back into the Paleozoic (Crame 2000, 2002; Alroy et al. 2008), and its strength appears to vary with mean global temperature (Crame 2000; Powell 2007; Mannion et al. 2014). How does the LLHG of marine bivalves vary among intervals with documented LDGs? Does the shallowing and steepening of thermal gradients, driven especially by high-latitude temperatures, allow for changes in life history that promote higher and lower taxon origination rates, respectively, in the mid-to-high latitudes? Data on taxon (stratigraphic) age distributions by latitude for warm and cool intervals in the past could help to test this hypothesis. However, range expansion out of the tropics is more likely during warm climate intervals, and taxa that successfully expand out of the tropics also tend to have higher speciation rates (Krug et al. 2008; Jablonski et al. 2013), so distinguishing between the two could prove difficult.

Body-Size Evolution and Energetics.-Body size is an important parameter in evolution, as it typically correlates with fecundity, metabolic rate, and population size (Brown et al. 1993). Ultimately determined by some combination of growth rate and life span, body size falls squarely in the sclerochronological domain. One of the more dramatic patterns in the marine fossil record is the increase in mean body size of animals over the Phanerozoic (Payne et al. 2009; Heim et al. 2015). The trend is evident within marine bivalves as well and appears to also hold true at the ordinal level (Fig. 7); Carditida, for example, shows an increase in mean body size of almost two orders of magnitude over its history. How is this pattern brought about-faster growth, longer life, or a subequal combination of both? Sclerochronological data are the key to test hypotheses related to any of these.

A propensity for faster growth rates toward present is consistent with hypothesized bioenergetic trends in the Phanerozoic history of marine life, the foundations of which were laid by Vermeij $(1977,1987)$ and Bambach (1993). Many authors (e.g., Signor and Brett 1984; Signor and Vermeij 1994; Martin 1996, 2003; Bambach 1999; Finnegan et al. 2011; Finnegan 2013; Allmon and Martin 2014; Payne et al. 2014; Knoll and Follows 2016; Martin and Servais 2020) have since argued for a general increase in metabolic activity in marine organisms through time fueled by factors including, but not limited to: changes in the diversity and abundance of marine phytoplankton, increased continental weathering rates due to the appearance of terrestrial plants, changes in seafloor spreading rates and the emplacement of large igneous provinces, and orogenic events and the subsequent increased nutrient loads to the oceans. While much of this work has been almost necessarily qualitative, Finnegan et al. (2011) attempted to quantify change in the metabolic rates of marine gastropods over the Mesozoic marine revolution using body-size and abundance data in concert with physiological data from living representatives. They argue for a $150 \%$ increase in mean metabolic rate between the Late Triassic and the Paleogene, consistent with the "seafood through time" (Bambach 1993) hypothesis. While their conclusions are tied to changes in body size, growth rates provided by increment data could verify this and provide 


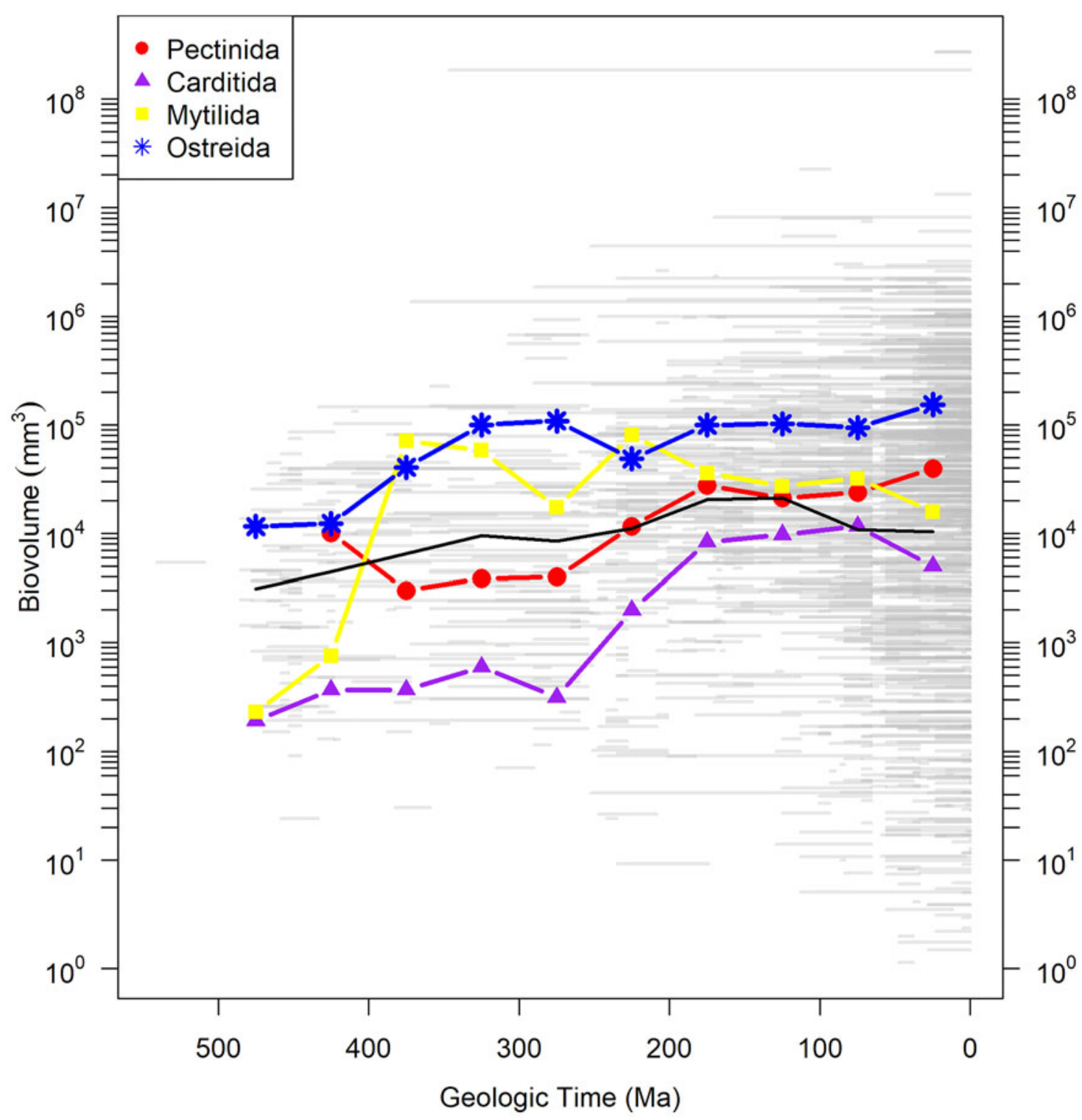

FIGURE 7. Biovolume of bivalve genera in four orders through the Phanerozoic derived from Heim et al. (2015) and plotted as body size of the largest measured species within each genus over the geologic range of the entire genus. Gray bars are geologic ranges. Colored lines with symbols show mean biovolume for orders in 50 Myr time bins. Black line is mean of all bivalves from the Heim et al. (2015) database. Note that the taxonomy used in Heim et al. (2015) follows that reported in the Paleobiology Database, which is based on Carter et al. (2011). (Color online.)

the ultimate test of the "seafood" hypothesis. Faster growth rates toward the present would also be consistent with an overall increase in predation pressure and the evolutionary arms race called for by escalation (Vermeij 1987), not unrelated to Bambach's "seafood."

Concomitant with the proposed increase in organism energetics is a now well-documented general increase in predation activity in the marine realm, recorded especially with benthic taxa (Vermeij et al. 1981; Signor and Brett 1984; Leighton 2002; Harper 2003, 2006; Kelley and Hansen 2006; Huntley and Kowalewski 2007). How do the life-history strategies of bivalves change in response to the appearance of new and perhaps more sophisticated predators 
over geologic time? Evidence of predation on Paleozoic marine benthic taxa is generally sparser, but not altogether absent (e.g., Sheehan and Lesperance 1978; Smith et al. 1985; Leighton 1999; Brett and Walker 2002; Nagel-Myers et al. 2009; Richards and Leighton 2012; Salamon et al. 2014). However, predation pressure increases in the Mesozoic (Vermeij 1987). From the perspective of bivalves, many of the mechanisms to avoid predation are behaviors that require a faster metabolic rate. These include, but are not limited to, higher calcification budgets associated with thicker (Kelley 1989, 1991) and more ornamented (Feifarek 1987; Harper and Skelton 1993; Dietl et al. 2000) skeletons, faster and deeper burrowing (Stanley 1968; Doering 1982; Palmer 1982; Harper 1991), and new escape methods such as swimming and leaping (Ansell 1969; Hayami 1991; Donovan et al. 2004). Higher metabolic rates equate to faster growth, and this generally correlates with shorter life spans (e.g., Van Voorhies 2001). High predation pressure itself also selects for faster growth to reach size refugia and early maturation so as to ensure successful reproduction before death (Stearns 1992; Brown and Sibly 2006). A different approach to dealing with high predation pressure is to retreat from it altogether to a place that cannot be accessed. A very deep burrow that renders many potential predators ineffective could allow animals like modern Panopea generosa the flexibility for life spans (up to 150 years; Bureau et al. 2002) longer than typically associated with their $k$ values (Moss et al. 2016; Fig. 4). Though there is some variability in age at first reproduction, modern $A$. islandica typically mature around 20-30 years (Thorarinsdóttir and Jacobson 2005), a strategy only allowed by low rates of predation. Lower predation pressure in the Paleozoic might therefore equate to slower growth and longer life spans. The life-history information gap is a roadblock to understanding the physiological responses of organisms to the Mesozoic marine revolution, and potentially other major macroevolutionary transitions in the history of life.

Extinction Selectivity.-The roles that life span and growth rate play in survival during extinctions and the recoveries that follow could be a missing piece of the narrative.
Many biodiversity crises are now known to be associated at least in part with a drop in primary production in the oceans, most famously the Cretaceous/Paleogene boundary mass extinction (Hsu and McKenzie 1985; Kump 1991; D’Hondt 2005; Kring 2007; Alegret et al. 2012; Sepúlveda et al. 2019). Selectivity among bivalves at the $\mathrm{K} / \mathrm{Pg}$ is complicated (Rhodes and Thayer 1991; Jablonski and Raup 1995; McClure and Bohonak 1995; Jablonski 1998; Lockwood 2003, 2004), but under such conditions, taxa with lower metabolic rates/ needs will tend to do better (Thayer 1986; Gallagher 1991; Rhodes and Thayer 1991; Landman et al. 2014). This is a testable hypothesis for bivalves, as surviving taxa, either within a fauna or globally, should tend to have slower growth and longer life spans in comparison to those that suffer extinction. In addition, high-latitude bivalves were less likely to go extinct than those inhabiting low-latitude settings (Vilhena et al. 2013). If an LLHG was present in the Cretaceous, the high latitudes would include more of these slower-growing and longer-lived species than elsewhere. What impact might selective survival of slowgrowing species with longer life spans and delayed sexual maturation have on recoveries? Life-history traits likely play a bigger role in patterns of survival during and recovery from mass extinctions than we realize.

\section{Conclusions}

Leonardo's astute observations that exterior lines on the shells of cockles, found high in the Italian mountains, represented the years and months of their lives paved the way from Neoplatonic or Diluvian explanations for the formation of fossils to scientific ones. In doing so, he provided perhaps one of the most fundamental revelations in the history of geology, that the Earth has a history independent of us. Life-span and growth rate data have been missing from our quest to understand how the so-called pageant of life has unfolded. Over the past few decades, sclerochronologists have developed the techniques necessary to extract this information from organisms with accretionary skeletons, with which the fossil record is rife. Uniting the techniques of 
sclerochronology with the evolutionary questions of paleobiology promised to "yield rich rewards" (McKinney and McNamara 1991, p. 370), but these have yet to be fully realized. We hope we have made clear that this combined approach offers new avenues of research and insight into not only heterochrony, but large-scale macroevolutionary and ecological patterns in space and time over the Phanerozoic. Reuniting paleobiology and sclerochronology once again foretells the potential for a formative step forward in the study of the history of life's evolution. We can hope that this time it sticks.

\section{Acknowledgments}

We thank the participants at the International Sclerochronology Conferences since 2007 for pushing us to consider these topics further. Thoughtful conversations with B. Runnegar and J. Brower helped to refine our thinking on these issues. I. Quitmyer provided Fig. 1, B. Schone provided Mutvei staining for Fig 6C, and L. Beierlein imaged Fig. 6A. We thank L. Harper and an anonymous reviewer for astute comments that improved the article. Parts of this paper derive from outgrowths of work supported by National Science Foundation PLR-1543031 and EAR-0719645 to L.C.I. The foundation that allows for this article was laid long ago by extended interactions with S. J. Gould. We miss his voice in this conversation.

\section{Literature Cited}

Abele, D., and E. Philipp. 2013. Environmental control and control of the environment: the basis of longevity in bivalves. Gerontology 59:261-266.

Abele, D., T. Brey, and E. Philipp. 2009. Bivalve models of aging and the determination of molluscan lifespans. Experimental Gerontology 44:307-315.

Alberch, P., S. J. Gould, G. F. Oster, and D. B. Wake. 1979. Size and shape in ontogeny and phylogeny. Paleobiology 5:296-317.

Alegret, L., E. Thomas, and K. C. Lohmann. 2012. End-Cretaceous marine mass extinction not caused by productivity collapse. Proceedings of the National Academy of Sciences USA 109:728-732.

Allmon, W. D., and R. E. Martin. 2014. Seafood through time revisited: the Phanerozoic increase in marine trophic resources and its macroevolutionary consequences. Paleobiology 40:256-287.

Alroy, J., M. Aberhan, D. J. Bottjer, M. Foote, F. T. Fürsich, P. J. Harries, A. J. W. Hendy, S. M. Holland, L. C. Ivany, W. Kiessling, M. S. Kosnik, S. R. Marshall, A. J. McGowran, A. I. Miller, T. D. Olszewski, M. E. Patzkowsky, S. E. Peters, L. Villier, P. J. Wagner, N. Bonuso, P. S. Borkow, B. Brenneis, M. E. Clapham, L. M. Fall, C. A. Furguson, V. L. Hanson, A.
Z. Krug, K. M. Layou, E. H. Leckey, S. Nürnberg, C. Powers, M., J. A. Sessa, C. Simpson, A. Tomašových, and C. C. Visaggi. 2008. Phanerozoic trends in the global diversity of marine invertebrates. Science 321:97-100.

Alvarez, M. J., and C. J. del Rio. 2020. Phylogeny of the Eocene Antarctic Tapetinae Gray, 1851 (Bivalvia, Veneridae) from the La Meseta and Submeseta formations. Journal of Paleontology 94:799-818.

Ambrose, W. G., D. S. Jones, and I. Thompson. 1980. Distance from shore and growth rate of the suspension feeding bivalve, Spisula solidissima. Proceedings of the National Shellfisheries Association 70:207-214

Anderson, L. C., and P. D. Roopnarine. 2003. Evolution and phylogenetic relationships of Neogene Corbulidae (Bivalvia; Myoidea) of tropical America. Journal of Paleontology 77:1086-1102.

Ansell, A. D. 1969. Defensive adaptations to predation in the Mollusca. Proceedings of the Symposium on the Mollusca 2:487-512. Aragón-Noriega, E. A., L. E. Calderon-Aguilera, and S. A. PérezValencia. 2015. Modeling growth of the Cortes Geoduck Panopea globosa from unexploited and exploited beds in the Northern Gulf of California. Journal of Shellfish Research 34:119-127.

Aronson, R. B., D. B. Blake, and T. Oji. 1997. Retrograde community structure in the late Eocene of Antarctica. Geology 25:903-906.

Ballesta-Artero, I., R. Witbaard, M. L. Carroll, and J. van der Meer. 2017. Environmental factors regulating gaping activity of the bivalve Arctica islandica in Northern Norway. Marine Biology 164:116.

Bambach, R. K. 1993. Seafood through time: changes in biomass, energetics, and productivity in the marine ecosystem. Paleobiology 19:372-397.

Bambach, R. K. 1999. Energetics in the global marine fauna: a connection between terrestrial diversification and change in the marine biosphere. Geobios 32:131-144.

Bartoo, N. W., and K. R. Parker. 1983. Stochastic age-frequency estimation using the von Bertalanffy growth equation. Fishery Bulletin 81:91-96.

Basova, L., S. Begum, J. Strahl, A. Sukhotin, T. Brey, E. Philipp, and D. Abele. 2012. Age-dependent patterns of antioxidants in Arctica islandica from six regionally separate populations with different lifespans. Aquatic Biology 14:141-152.

Bauer, G. 1992. Variation in the life span and size of the freshwater pearl mussel. Journal of Animal Ecology 61:425-436.

Beard, J. A., L. C. Ivany, and B. Runnegar. 2015. Gradients in seasonality and seawater oxygen isotopic composition along the early Permian Gondwanan coast, SE Australia. Earth and Planetary Science Letters 425:219-231.

Belding, D. L. 1910. The growth and habits of the sea clam (Mactra solidissima). Reports of the Commissioner of Fish and Game 25:26-41.

Bertalanffy, L. von 1938. A quantitative theory of organic growth (inquiries on growth laws. II). Human Biology 10:181-213.

Bettoli, P. W., and L. E. Miranda. 2001. Cautionary note about estimating mean length at age with subsampled data. North American Journal of Fisheries Management 21:425-428.

Bieler, R., P. M. Mikkelsen, T. M. Collins, E. A. Glover, V. L. González, D. L. Graf, E. M. Harper, J. Healy, G. Y. Kawauchi, P. P. Sharma, S. Staubach, E. E. Strong, J. D. Taylor, I. Tëmkin, J. D. Zardus, S. Clark, A. Guzmán, E. McIntyre, P. Sharp, and G. Giribet. 2014. Investigating the Bivalve Tree of Life-an exemplar-based approach combining molecular and novel morphological characters. Invertebrate Systematics 28:32-115.

Brand, U. 1982. The oxygen and carbon isotope composition of Carboniferous fossil components: sea-water effects. Sedimentology 29:139-147.

Brett, C. E., and S. E. Walker. 2002. Predators and predation in Paleozoic marine environments. Paleontological Society Papers 8:93-118. 
Brey, T., and A. Clarke. 1993. Population dynamics of marine benthic invertebrates in Antarctic and subantarctic environments: are there unique adaptations? Antarctic Science 5:253-266.

Brocas, W. M., D. J. Reynolds, P. G. Butler, C. A. Richardson, J. D. Scourse, I. D. Ridgway, and K. Ramsay. 2013. The dog cockle, Glycymeris glycymeris (L.), a new annually-resolved sclerochronological archive for the Irish Sea. Palaeogeography, Palaeoclimatology, Palaeoecology 373:133-140.

Brown, J. H., and R. M. Sibly. 2006. Life-history evolution under a production constraint. Proceedings of the National Academy of Sciences USA 103:17595-17599.

Brown, J. H., P. A. Marquest, and M. L. Taper. 1993. Evolution of body size: consequences of an energetic definition of fitness. American Naturalist 142:573-584.

Buick, D. P., and L. C. Ivany. 2004. 100 years in the dark: extreme longevity of Eocene bivalves from Antarctica. Geology 32:921-924.

Bureau, D., W. Hajas, N. W. Surry, C. M. Hand, G. Dovey, and A. Campbell. 2002. Age, size structure and growth parameters of Geoducks (Panopea abrupta, Conrad 1849) from 34 locations in British Columbia sampled between 1993 and 2000. Canadian Technical Reports of Fisheris and Acquatic Sciences 2949:1-29.

Bušelić, I., M. Peharda, D. J. Reynolds, P. G. Butler, A. R. González, D. Ezgeta-Balić, I. Vilibić, B. Grbec, P. Hollyman, and C. A. Richardson. 2015. Glycymeris bimaculata (Poli, 1795) - a new sclerochronological archive for the Mediterranean? Journal of Sea Research 95:139-148.

Butler, P. G., A. D. Wanamaker, J. D. Scourse, C. A. Richardson, and D. J. Reynolds. 2013. Variability of marine climate on the North Icelandic Shelf in a 1357-year proxy archive based on growth increments in the bivalve Arctica islandica. Palaeogeography, Palaeoclimatology, Palaeoecology 373:141-151.

Carter, J. G., C. R. Altaba, L. C. Anderson, R. Araujo, A. S. Biakov, A. E. Bogan, D. C. Campbell, M. Campbell, C. Jin-hua, J. C. W. Cope, G. Delvene, H. H. Dijkstra, F. Zong-jie, R. N. Gardner, V. A. Gavrilova, I. A. Goncharova, P. J. Harries, J. H. Hartman, M. Hautmann, W. R. Hoeh, J. Hylleberg, J. Bao-yu, P. Johnston, L. Kirkendale, K. Kleemann, J. Koppka, J. Kriz, D. Machado, N. Malchus, A. Márquez-aliaga, J. Masse, C. A. Mcroberts, P. Middlefart, S. Mitchell, L. A. Nevesskaja, S. Özer, J. Pojeta Jr., I. V Polubotko, M. Pons, S. Popov, T. Sánchez, A. F. Sartori, R. W. Scott, I. I. Sey, J. H. Signorelii, V. V Silantiev, P. W. Skelton, T. Steuber, J. B. Waterhouse, G. L. Wingard, and T. Yancey. 2011. A snynoptical classification of the Bivalvia (Mollusca). Paleontological Contributions 4:1-47.

Cassista, M. C., and M. W. Hart. 2007. Spatial and temporal genetic homogeneity in the Arctic surfclam (Mactromeris polynyma). Marine Biology 152:569-579.

Chamberlin, T. K. 1931. Annual growth of fresh-water mussels. Bulletin of the Bureau of Fisheries 1103:713-739.

Chamberlin, T. K. 1933. Ages and shell measurements of two large speciemens of Megalonaias gigantea Barnes. The Nautilus 47:29-30.

Clapham, M. E. 2017. Organism activity levels predict marine invertebrate survival during ancient global change extinctions. Global Change Biology 23:1477-1485.

Clark, G. R. 1974. Growth lines in invertebrate skeletons. Annual Review of Earth and Planetary Sciences 2:77-99.

Clarke, A. and J. A. Crame. 2010. Evolutionary dynamics at high latitudes: speciation and extinction in polar marine faunas. Philosophical Transactions of the Royal Society of London B 365:3655-3666.

Clarke, A., T. Brey, and A. Clarke. 1993. Population dynamics of marine benthic invertebrates in Antarctic and subantarctic environments: are there unique adaptations? Antarctic Science 5:253266.

Collins, K. S., J. S. Crampton, H. L. Neil, G. C. Euan, M. F. Gazley, K. S. Collins, J. S. Crampton, H. L. Neil, E. G. C. Smith, and M. F. Gazley. 2016. Anchors and snorkels: heterochrony, development and form in functionally constrained fossil crassatellid bivalves. Paleobiology 42:305-316.
Combosch, D. J., and G. Giribet. 2016. Clarifying phylogenetic relationships and the evolutionary history of the bivalve order Arcida (Mollusca:Bivalvia:Pteriomorphia). Molecular Phylogenetics and Evolution 94:298-312.

Crame, A. J. 2000. Evolution of taxonomic diversity gradients in the marine realm: evidence from the composition of Recent bivalve faunas. Paleobiology 26:188-214.

Crame, A. J. 2002. Evolution of taxonomic diversity gradients in the marine realm: a comparison of Late Jurassic and Recent bivalve faunas. Paleobiology 28:184-207.

D'Hondt, S. 2005. Consequences of the Cretaceous/Paleogene mass extinction for marine ecosystems. Annual Review of Ecology, Evolution, and Systematics 36:295-317.

Dietl, G. P., R. R. Alexander, and W. F. Bien. 2000. Escalation in Late Cretaceous-early Paleocene oysters (Gryphaeidae) from the Atlantic Coastal Plain. Paleobiology 26:215-237.

Doering, P. H. 1982. Reduction of sea star predation by the burrowing response of the hard clam Mercenaria. Estuaries 5:310-315.

Donovan, D. A., J. P. Elias, and J. Baldwin. 2004. Swimming behavior and morphometry of the file shell Limaria fragilis. Marine and Freshwater Behaviour and Physiology 37:7-16.

Douglas, P. M. J., H. P. Affek, L. C. Ivany, A. J. P. Houben, W. P. Sijp, A. Sluijs, S. Schouten, and M. Pagani. 2014. Pronounced zonal heterogeneity in Eocene southern high-latitude sea surface temperatures. Proceedings of the National Academy of Sciences USA 111:6582-6587.

Elliot, M., P. B. DeMenocal, B. K. Linsley, and S. S. Howe. 2003. Environmental controls on the stable isotopic composition of Mercenaria mercenaria: potential application to paleoenvironmental studies. Geochemistry, Geophysics, Geosystems 4. doi: 10.1029/2002GC000425.

Epstein, S., R. Buchsbaum, H. A. Lowenstam, and H. C. Urey. 1953. Revised carbonate-water isotopic temperature scale. Bulletin of the Geological Society of America 64:1315-1326.

Erickson, J. M., and B. D. Palmateer. 1996. Paleobiology and stratigraphy of Panopea occidentalis in life position in the Fox Hills Formation (Late Cretaceous: Maastrichtian) of North Dakota. Proceedings of the North Dakota Academy of Science 50:35.

Feifarek, B. P. 1987. Spines and epibionts as antipredator defenses in the thorny oyster Spondylus americanus Hermann. Journal Experimental Marine Biology and Ecology 105:39-56.

Feng, Y., Q. Li, and L. Kong. 2015. Molecular phylogeny of Arcoidea with emphasis on Arcidae species (Bivalvia: Pteriomorphia) along the coast of China: challenges to current classification of Arcoids. Molecular Phylogenetics and Evolution 85:189-196.

Finnegan, S. 2013. Quantifying seafood through time: counting calories in the fossil record. Paleontological Society Papers 19:21-50.

Finnegan, S., C. McClain, M. A. Kosnik, and J. L. Payne. 2011. Escargots through time: an energetic comparison of marine gastropod assemblages before and after the Mesozoic Marine Revolution. Paleobiology 37:252-269.

Fridriksson, A. 1934. On the calculation of age-distribution within a stock of cod by means of relatively few age-determinations as a key to measurements on a large scale. Rapports et ProcesVerbaux des Reunions Commission Internationale Pour 1'Exploration Scientifique de la Mer Mediterranee Monaco 6:1-5.

Fritz, L. W. 1991. Seasonal condition change, morphometrics, growth and sex ratio of the ocean quahog, Arctica islandica (Linnaeus, 1767) off New Jersey, USA. Journal of Shellfish Research 10:79-88.

Galinous-Mitsoudi, S., and A. I. Sinis. 1995. Age and growth of Lithophaga lithophaga (Linnaeus, 1758) (Bivalvia: Mytilidae), based on annual growth lines in the shell. Journal of Molluscan Studies 61:435-453.

Gallagher, W. B. 1991. Selective extinction and survival across the Cretaceous/Tertiary boundary in the northern Atlantic Coastal Plain. Geology 19:967-970. 
Gallucci, V. F., and T. J. Quinn. 1979. Reparameterizing, fitting, and testing a simple growth model. Transactions of the American Fisheries Society 108:14-25.

Geary, D. H., E. Hoffmann, I. Magyar, J. Freiheit, and D. Padilla. 2012. Body size, longevity, and growth rate in Lake Pannon melanopsid gastropods and their predecessors. Palaeobiology 38:554-568.

Giebel, C. G. 1856. Die versteinerungen in muschelkalk von Lieskau bei Halle. Abhandlungen Naturwissenschaftlichen Vereines 1:53-126

Gillikin, D. P., A. Lorrain, J. Navez, J. W. Taylor, L. Andre, E. Keppens, W. Baeyens, and F. Dehairs. 2005. Strong biological controls on $\mathrm{Sr} / \mathrm{Ca}$ ratios in aragonitic marine bivalve shells. Geochemistry, Geophysics, Geosystems 6:1-16.

Gillilan, W. 1964. Pismo clam survey. Outdoor California 25:10-11.

Gimenez, L. H., M. del S. Doldan, P. C. Zaidman, and E. M. Morsan. 2020. The potential of Glycymeris longior (Mollusca, Bivalvia) as a multi-decadal sclerochronological archive for the Argentine Sea (Southern Hemisphere). Marine Environmental Research 155:104879.

Goodwin, D. H., K. W. Flessa, B. R. Schöne, and D. L. Dettman. 2001. Cross-calibration of daily growth increments, stable isotope variation, and temperature in the Gulf of California bivalve mollusk Chione cortezi: implications for paleoenvironmental analysis. Palaios 16:387-398.

Goodwin, D. H., L. C. Anderson, and P. D. Roopnarine. 2008. Evolutionary origins of novel conchologic growth patterns in tropical American corbulid bivalves. Evolution and Development 10:642656.

Gould, S. J. 1977. Ontogeny and phylogeny. Harvard University Press, Cambridge, Mass.

Gould, S. J. and C. B. Calloway. 1980. Clams and brachiopodsships that pass in the night. Paleobiology 6:383-396.

Gribben, P. E., and R. G. Creese. 2005. Age, growth, and mortality of the New Zealand geoduck clam, Panopea zelandica (Bivalvia: Hiatellidae) in two North Island populations. Bulletin of Marine Science 77:119-135.

Grossman, E. L. 2012. Applying oxygen isotope paleothermometry in deep time. In L. C. Ivany and B. T. Huber, eds. Reconstructing Earth's deep-time climate - the state of the art in 2012. Paleontological Society Papers 18:39-67.

Grossman, E. L., and T. L. Ku. 1986. Oxygen and carbon isotope fractionation in biogenic aragonite: temperature effects. Chemical Geology: Isotope Geoscience Section 59:59-74.

Hallmann, N., B. R. Schöne, A. Strom, and J. Fiebig. 2008. An intractable climate archive-sclerochronological and shell oxygen isotope analyses of the Pacific geoduck, Panopea abrupta (bivalve mollusk) from Protection Island (Washington State, USA). Palaeogeography, Palaeoclimatology, Palaeoecology 269:115-126.

Hamner, W. M., and M. S. Jones. 1976. Distribution, burrowing, and growth rates of the clam Tridacna crocea on interior reef flats-formation of structures resembling micro atolls. Oecologia 24:207227.

Harding, J. 2007. Northern quahog (=hard clam) Mercenaria mercenaria age at length relationships and growth patterns in the York River, Virginia 1954 to 1970. Journal of Shellfish Research 26:101-107.

Harper, E. M. 1991. The role of predation in the evolution of cementation in bivalves. Palaeontology 34:455-460.

Harper, E. M. 2003. Assessing the importance of drilling predation over the Palaeozoic and Mesozoic. Palaeogeography, Palaeoclimatology, Palaeoecology 201:185-198.

Harper, E. M. 2006. Dissecting post-Palaeozoic arms races. Palaeogeography, Palaeoclimatology, Palaeoecology 232:322-343.

Harper, E. M., and P. W. Skelton. 1993. The Mesozoic Marine Revolution and epifaunal bivalves. Scripta Geologica, Special Issue 2:127-153.
Harper, E. M., J. A. Crame, and C. E. Sogot. 2018. "Business as usual": drilling predation across the K-Pg mass extinction event in Antarctica. Palaeogeography, Palaeoclimatology, Palaeoecology 498:115-126.

Hayami, I. 1991. Living and fossil scallop shells as airfoils: an experimental study. Paleobiology 17:1-18.

Heim, N. A., M. L. Knope, E. K. Schaal, S. C. Wang, and J. L. Payne. 2015. Cope's rule in the evolution of marine animals. Science 347:867-870.

Hopcroft, P. O., G. Ramstein, T. A. M. Pugh, S. J. Hunter, F. Murguia-Flores, A. Quiquet, Y. Sun, N. Tan, and P. J. Valdes. 2020. Polar amplification of Pliocene climate by elevated trace gas radiative forcing. Proceedings of the National Academy of Sciences USA 117:23401-23407.

Hsieh, S., A. M. Bush, and J. B. Bret. 2019. Were bivalves ecologically dominant over brachiopods in the late Paleozoic? A test using exceptionally preserved fossil assemblages. Paleobiology 45:265-279.

Hsu, K. J., and J. A. McKenzie. 1985. A "Strangelove" ocean in the earliest Tertiary. In E. T. Sundquist and W. S. Broecker, eds. The carbon cycle and atmospheric $\mathrm{CO}_{2}$ : natural variations Archean to present. American Geophysical Union Monograph 32:487-492.

Huntley, J. W., and M. Kowalewski. 2007. Strong coupling of predation intensity and diversity in the Phanerozoic fossil record. Proceedings of the National Academy of Sciences USA 104:1500615010.

Ivany, L. C. 2012. Reconstructing paleoseasonality from accretionary skeletal carbonates - challenges and opportunities. In L. C. Ivany and B. T. Huber, eds. Reconstructing Earth's deeptime climate- the state of the art in 2012. Paleontological Society Papers 18:133-165.

Ivany, L. C., and B. Runnegar. 2007. Primary isotope ratios preserved in a Late Permian bivalve allow for life history and paleoenvironmental reconstructions. Paper presented at the First International Sclerochronology Conference, St. Petersburg, Fla., July 2007

Ivany, L. C., and B. Runnegar. 2010. Early Permian seasonality from bivalve $\delta^{18} \mathrm{O}$ and implications for the oxygen isotopic composition of seawater. Geology 38:1027-1030.

Ivany, L. C., K. C. Lohmann, F. Hasiuk, D. B. Blake, A. Glass, R. B. Aronson, and R. M. Moody. 2008. Eocene climate record of a high souther latitude continental shelf: Seymour Island, Antarctica. GSA Bulletin 120:659-678.

Ivany, L. C., T. Brey, M. Huber, D. P. Buick, and B. R. Schöne. 2011. El Nino in the Eocene greenhouse recorded by fossil bivalves and wood from Antarctica. Geophysical Research Letters 38:2-7.

Jablonski, D. 1998. Geographic variation in the molluscan recovery from the end-Cretaceous extinction. Science 279:1327-1330.

Jablonski, D., and D. M. Raup. 1995. Selectivity of End-Cretaceous marine bivalve extinctions. Science 268:389-391.

Jablonski, D., K. Roy, and J. W. Valentine. 2006. Out of the tropics: evolutionary dynamics of the latitudinal diversity gradient. Science 314:102-106.

Jablonski, D., C. L. Belanger, S. K. Berke, S. Huang, A. Z. Krug, and K. Roy. 2013. Out of the tropics, but how? fossils, bridge species, and thermal ranges in the dynamics of the marine latitudinal diversity gradient. Proceedings of the National Academy of Sciences USA 110:10487-10494.

Jablonski, D., S. Huang, K. Roy, and J. W. Valentine. 2017. Shaping the latitudinal diversity gradient: new perspectives from a synthesis of paleobiology and biogeography. American Naturalist 189:1-12.

Jell, P. A. 1980. Earliest known pelecypod on Earth-a new Early Cambrian genus from South Australia. Alcheringa, 4:233-239.

Jimenez, M. Y., L. C. Ivany, E. J. Judd, and G. Henkes. 2019. Low and seasonally variable salinity in the Pennsylvanian equatorial Appalachian Basin. Earth and Planetary Science Letters 519:182-191. 
Johnson, A. L. A., E. M. Harper, A. Clarke, C. Aaron, D. J. Heywood, K. E. Richardson, J. O. Spink, and L. A. H. Thornton, 2019. Growth rate, extinction and survival amongst late Cenozoic bivalves of the North Atlantic. Historical Biology. doi: 10.1080/ 08912963.2019.1663839.

Jones, D. S. 1980. Annual cycle of shell growth increment formation in two continental shelf bivalves and its paleoecologic significance. Paleobiology 6:331-340.

Jones, D. S. 1981. Repeating layers in the molluscan shell are not always periodic. Journal of Paleontology 55:1076-1082.

Jones, D. S. 1983. Sclerochronology: reading the record of the molluscan shell. American Scientist 71:384-391.

Jones, D. S. 1988. Sclerochronology and the size versus age problem. Pp. 93-108 in M. L. McKinney, ed. Heterochrony in evolution. Plenum, New York.

Jones, D. S., and S. J. Gould. 1999. Direct measurement of age in fossil Gryphaea: the solution to a classic problem in heterochrony. Paleobiology 25:158-187.

Jones, D. S., and I. R. Quitmyer. 1996. Marking time with bivalve shells: oxygen isotopes and season of annual increment formation. Palaios 11:340-346.

Jones, D. S., I. Thompson, and W. Ambrose. 1978. Age and growth rate determinations for the Atlantic surf clam Spisula solidissima (Bivalvia: Mactracea), based on internal growth lines in shell cross-sections. Marine Biology 47:63-70.

Jones, D. S., D. F. Williams, and M. A. Arthur. 1983. Growth history and ecology of the Atlantic Surf Clam, Spisula solidissima (Dillwyn), as revealed by stable isotopes and annual shell increments. Journal Experimental Marine Biology and Ecology 73:225-242.

Jones, D. S., M. A. Arthur, and D. J. Allard. 1989. Sclerochronological records of temperature and growth from shells of Mercenaria mercenaria from Narragansett Bay, Rhode Island. Marine Biology 102:225-234

Jones, D. S., I. R. Quitmyer, and C. F. T. Andrus. 2005. Oxygen isotopic evidence for greater seasonality in Holocene shells of Donax variabilis from Florida. Palaeogeography, Palaeoclimatology, Palaeoecology 228:96-108

Judd, E. J., L. C. Ivany, R. M. DeConto, A. R. W. Halberstadt, N. M. Miklus, C. K. Junium, and B. T. Uveges. 2019. Seasonally resolved proxy data from the Antarctic Peninsula support a heterogeneous middle Eocene Southern Ocean. Paleoceanography and Paleoclimatology 34:787-799.

Kelley, P. H. 1989. Evolutionary trends within bivalve prey of Chesapeake Group naticid gastropods. Historical Biology 2:139-156.

Kelley, P. H. 1991. The effect of predation intensity on rate of evolution of five Miocene bivalves. Historical Biology 5:65-78.

Kelley, P. H., and T. A. Hansen. 2006. Latitudinal patterns in naticid gastropod predation along the East Coast of the United States: a modern baseline for interpreting temporal patterns in the fossil record. SEPM Special Publication 88:287-299.

Kilada, R. W., S. E. Campana, and D. Roddick. 2009. Growth and sexual maturity of the northern propeller clam (Cyrtodaria siliqua) in Eastern Canada, with bomb radiocarbon age validation. Marine Biology 156:1029-1037.

Killam, D. E., and M. E. Clapham. 2018. Identifying the ticks of bivalve shell clocks: seasonal growth in relation to temperature and food supply. Palaios 33:228-236.

Kimura, D. K. 1977. Statistical assessment of the age-length key. Journal of the Fisheries Research Board of Canada 34:317-324.

Knoll, A. H., and M. J. Follows. 2016. A bottom-up perspective on ecosystem change in Mesozoic oceans. Proceedings of the Royal Society of London B 283:20161755.

Kong, L., Y. Li, K. M. Kocot, Y. Yang, L. Qi, Q. Li, and K. M. Halanych. 2020. Mitogenomics reveals phylogenetic relationships of Arcoida (Mollusca, Bivalvia) and multiple independent expandsion and contractions in mitochondrial genome size. Molecular Phylogenetics and Evolution 150. doi: 10.1016/j.ympev.2020.106857.
Kring, D. A. 2007. The Chicxulub impact event and its environmental consequences at the Cretaceous-Tertiary boundary. Palaeogeography, Palaeoclimatology, Palaeoecology 255:4-21.

Krug, A. Z., D. Jablonski, and J. W. Valentine. 2008. Species-genus ratios reflect a global history of diversification and range expansion in marine bivalves. Proceedings of the Royal Society of London B 275:1117-1123.

Kump, L. R. 1991. Interpreting carbon-isotope excursions: Strangelove oceans. Geology 19:299-302.

Landman, N. H., S. Goolaerts, J. W. Jagt, E. A. Jagt-Yazykova, M. Machalski, and M. M. Yacobucci. 2014. Ammonite extinction and nautilid survival at the end of the Cretaceous. Geology 42:707-710.

Lapworth, C., and J. Wilson. 1871. On the Silurian rocks of the counties of Roxburgh and Selkirk. Geological Magazine 8:456-464.

Leesen, G. von, L. Beierlein, D. Scarponi, B. R. Schöne, and T. Brey. 2017. A low seasonality scenario in the Mediterranean Sea during the Calabrian (Early Pleistocene) inferred from fossil Arctica islandica shells. Palaeogeography, Palaeoclimatology, Palaeoecology 485:706-714.

Leighton, L. R. 1999. Possible latitudinal predation gradient in middle Paleozoic oceans. Geology 27:47-50.

Leighton, L. R. 2002. Inferring predation intensity in the marine fossil record. Paleobiology 28:328-342.

Liow, L. H., T. Reitan, and P. G. Harnik. 2015. Ecological interactions on macroevolutionary time scales: clams and brachiopods are more than ships that pass in the night. Ecology Letters 18:1030-1039.

Lockwood, R. 2003. Abundance not linked to survival across the end-Cretaceous mass extinction: patterns in North American bivalves. Proceedings of the National Academy of Sciences USA 100:2478-2482.

Lockwood, R. 2004. The K/T event and infaunality: morphological and ecological patterns of extinction and recovery in veneroid bivalves. Paleobiology 30:507-521.

Lomovasky, B. J., T. Brey, E. Morriconi, and J. Calvo. 2002. Growth and production of the venerid bivalve Eurhomalea exalbida in the Beagle Channel, Tierra del Fuego. Journal of Sea Research 48:209-216.

Lunt, D. J., A. M. Haywood, G. A. Schmidt, U. Salzmann, P. J. Valdes, H. J. Dowsett, and C. A. Loptson. 2012. On the causes of mid-Pliocene warmth and polar amplification. Earth and Planetary Science Letters 321-322:128-138.

Lutz, R. A., and D. C. Rhoads. 1977. Anaerobiosis and a theory of growth line formation. Science 198:1222-1227.

Lutz, R. A., and D. C. Rhoads. 1980. Growth patterns within the molluscan shell. Pp. 203-254 in D. C. Rhoads and R. A. Lutz, eds. Skeletal growth of aquatic organisms. Plenum, New York.

Mannion, P. D., P. Upchurch, R. B. J. Benson, and A. Goswami. 2014. The latitudinal biodiversity gradient through deep time. Trends in Ecology and Evolution 29:42-50.

Martin, R. E. 1996. Secular increase in nutrient levels through the Phanerozoic: implications for productivity, biomass, diversity, and extinction of the marine biosphere. Palaios 11:209-219.

Martin, R. E. 2003. The fossil record of biodiversity: nutrients, productivity, habitat area and differential preservation. Lethaia 36:179-193.

Martin, R. E., and T. Servais. 2020. Did the evolution of the phytoplankton fuel the diversification of the marine biosphere? Lethaia 53:5-31.

Masoro, E. J. 2000. Caloric restriction and aging: an update. Experimental Gerontology 35:299-305.

McClure, M., and A. J. Bohonak. 1995. Non-selectivity in extinction of bivalves in the Late Cretaceous of the Atlantic and Gulf Coastal Plain of North America. Journal of Evolutionary Biology 8:779-787. 
McClure, K. J., and R. Lockwood. 2015. Relationships among Venericardia (Bivalvia: Carditidae) on the U.S. Coastal Plain during the Paleogene. Journal of Paleontology 89:522-531.

McKinney, M. L., and K. J. McNamara. 1991. Heterochrony-the evolution of ontogeny. Plenum Press, New York.

Mette, M. J., A. D. Wanamaker, M. L. Carroll, W. G. Ambrose, and M. J. Retelle. 2016. Linking large-scale climate variability with Arctica islandica shell growth and geochemistry in northern Norway. Limnology and Oceanography 61:748-764.

Morsan, E., P. Zaidman, M. Ocampo-Reinaldo, and N. Ciocco. 2010. Population structure, distribtuion and harvesting of southern geoduck Panopea abbretviata, in San Matias Gulf (Patagonia, Argentina). Scientia Marina 74:763-772.

Moss, D. K., L. C. Ivany, E. J. Judd, P. W. Cummings, C. E. Bearden, W. J. Kim, E. G. Artruc, and J. R. Driscoll. 2016. Lifespan, growth rate, and body size across latitude in marine bivalvia, with implications for Phanerozoic evolution. Proceedings of the Royal Society of London B 283:20161364.

Moss, D. K., L. C. Ivany, R. B. Silver, J. Schue, and E. G. Artruc. 2017. High-latitude settings promote extreme longevity in fossil marine bivalves. Paleobiology 43:365-382.

Murawski, S. A., J. W. Ropes, and F. M. Serchuk. 1982. Growth of the ocean quahog, Arctica islandica, in the Middle Atlantic Bight. Fishery Bulletin 80:21-34.

Mutvei, H. 1979. On the internal structures of the nacreous tablets in molluscan shells. Scanning Electron Microscopy 2:457-462.

Nabholz, B., S. Glemin, N. Galtier, S. Glémin, N. Galtier, S. Glemin, and N. Galtier. 2008. Strong variations of mitochondrial mutation rate across mammals - the longevity hypothesis. Molecular Biology and Evolution 25:120-130.

Nagel-Myers, J., G. P. Dietl, and C. E. Brett. 2009. First report of sublethal breakage-induced predation on Devonian bivalves. Palaios 24:460-465.

Nakaoka, M. 1994. Size-dependent reproductive traits of Yoldia notabilis (Bivalvia: Protobranchia). Marine Ecology Progress Series 114:129-137.

Nedoncelle, K., F. Lartaud, L. Contreira Pereira, M. Yücel, A. M. Thurnherr, L. Mullineaux, and N. Le Bris. 2015. Bathymodiolus growth dynamics in relation to environmental fluctuations in vent habitats. Deep-Sea Research, part I (Oceanographic Research Papers) 106:183-193.

Nützel, A., Joachimski, M., and Correa, M.L. 2010. Seasonal climatic flucuations in the Late Triassic tropics-high-resolution oxygen isotope records from aragonitic bivalves (Cassian Formation, Northern Italy). Palaeogeography, Palaeoclimatology, Palaeoecology 285:194-204.

Oliver, P.G., and A. M. Holmes. 2006. The Arcoidea (Mollusca: Bivalvia): a review of the current phenetic-based systematics. Zoological Journal of the Linnean Society 148:237-251.

Orton, J. H. 1923. On the significance of "rings" on the shells of Cardium and other molluscs. Nature 112:10.

Pace, S. M., E. N. Powell, R. Mann, M. C. Long, and J. M. Klinck. 2017. Development of an age-frequency distribution for ocean quahogs (Arctica islandica) on Georges Bank. Journal of Shellfish Research 36:41-53.

Palmer, K. L., D. K. Moss, D. Surge, and S. Turek. 2021. Life history patterns of modern and fossil Mercenaria spp. from warm vs. cold climates. Palaeogeography, Palaeoclimatology, Palaeoecology. doi: 10.1016/j.palaeo.2021.110227.

Palmer, T. J. 1982. Cambrian to Cretaceous changes in hardground communities. Lethaia 15:309-323.

Pannella, G. 1976. Tidal growth patterns in recent and fossil mollusc bivalve shells: a tool for the reconstruction of paleotides. Die Naturwissenschaften 63:539-543.

Pannella, G., and C. MacClintock. 1968. Biological and environmental rhythms reflected in molluscan shell growth. Paleontological Society Memoir 2:64-80.
Payne, J. L., A. G. Boyer, J. H. Brown, S. Finnegan, M. Kowalewski, R. A. Krause, S. K. Lyons, C. R. McClain, D. W. McShea, P. M. Novack-Gottshall, F. A. Smith, J. A. Stempien, and S. C. Wang. 2009. Two-phase increase in the maximum size of life over 3.5 billion years reflects biological innovation and environmental opportunity. Proceedings of the National Academy of Sciences USA 106:24-27.

Payne, J. L., C. R. McClain, A. G. Boyer, J. H. Brown, S. Finnegan, M. Kowalewski, R. A. Krause Jr., S. K. Lyons, D. W. McShea, P. M. Novack-Gottshall, F. A. Smith, P. Spaeth, J. A. Stempien, and S. C. Wang. 2011. The evolutionary consequences of oxygenic photosynthesis: a body size perspective. Photosynthesis Research 107:37-57.

Payne, J. L., N. A. Heim, M. L. Knope, and C. R. McClain. 2014. Metabolic dominance of bivalves predates brachiopod diversity decline by more than 150 million years. Proceedings of the Royal Society of London B 281:20133122.

Pearson, R. G., and J. L. Munro. 1991. Growth, mortality and recruitment rates of giant clams, Tridacna gigas and T. derasa, at Michaelmas Reef, central Great Barrier Reef, Australia. Australian Journal of Marine and Freshwater Research 42:241-262.

Peck, L. S., and L. W. Bullough. 1993. Growth and population structure in the infaunal bivalve Yoldia eightsi in relation to iceberg activity at Signy Island, Antarctica. Marine Biology 117:235-241.

Peck, L. S., and L. Z. Conway. 2000. The myth of metabolic cold adaptation: oxygen consumption in stenothermal Antarctic bivalves. 1. In E. M. Harper, J. D. Taylor, and J. A. Crame, eds. The evolutionary biology of the Bivalvia. Geological Society London Special Publication 177:441-450.

Peharda, M., M. Crnčević, I. Bušelić, C. A. Richardson, and D. Ezgeta-Balić. 2012. Growth and longevity of Glycymeris nummaria (Linnaeus, 1758) from the eastern Adriatic, Croatia. Journal of Shellfish Research 31:947-950.

Peharda, M., B. A. Black, A. Purroy, and H. Mihanovi. 2016. The bivalve Glycymeris pilosa as a multidecadal environmental archive for the Adriatic and Mediterranean Seas. Marine Environmental Research 119:79-87.

Peharda, M., I. Vilibić, B. A. Black, K. Markulin, N. Dunić, T. Džoić, H. Mihanović, M. Gačić, S. Puljas, and R. Waldman. 2018. Using bivalve chronologies for quantifying environmental drivers in a semi-enclosed temperate sea. Scientific Reports 8:5559.

Petersen, S. V., A. Dutton, and K. C. Lohmann. 2016. EndCretaceous extinction in Antarctica linked to both Deccan volcanism and meteorite impact via climate change. Nature Communications 7:12079.

Peterson, C. H. 1986. Quantitative allometry of gamete production by Mercenaria mercenaria into old age. Marine Ecology Progress Series 29:93-97.

Philipp, E. E., and D. Abele. 2010. Masters of longevity: lessons from long-lived bivalves - a mini-review. Gerotnology 56:55-65.

Poulain, C., D. P. Gillikin, J. Thébault, J. M. Munaron, M. Bohn, R. Robert, Y. M. Paulet, and A. Lorrain. 2015. An evaluation of $\mathrm{Mg} / \mathrm{Ca}, \mathrm{Sr} / \mathrm{Ca}$, and $\mathrm{Ba} / \mathrm{Ca}$ ratios as environmental proxies in aragonite bivalve shells. Chemical Geology 396:42-50.

Powell, M. G. 2007. Latitudinal diversity gradients for brachiopod genera during Late Palaeozoic time: links between climate, biogeography and evolutionary rates. Global Ecology and Biogeography 16:519-528.

Pyenson, N. D., and G. J. Vermeij. 2016. The rise of ocean giants: maximum body size in Cenozoic marine mammals as an indicator for productivity in the Pacific and Atlantic Oceans. Biology Letters 12:20160186.

Quitmyer, I. R., D. S. Jones, and W. S. Arnold. 1997. The sclerochronology of hard clams, Mercenaria spp., from the South-Eastern U.S.A.: a method of elucidating the zooarchaeological records of seasonal resource procurement and seasonality in prehistoric shell middens. Journal of Archaeological Science 24:825-840. 
Reed, A. J., J. A. Godbold, L. J. Grange, and M. Solan. 2020. Growth of marine ectotherms is regionally constrained and asymmetric with latitude. Global Ecology and Biogeography doi: 10.1111/ geb.13245.

Reynolds, D. J., P. G. Butler, S. M. Williams, J. D. Scourse, C. A. Richardson, A. D. Wanamaker, W. E. N. Austin, A. G. Cage, and M. D. J. Sayer. 2013a. A multiproxy reconstruction of Hebridean (NW Scotland) spring sea surface temperatures between AD 1805 and 2010. Palaeogeography, Palaeoclimatology, Palaeoecology 386:275-285.

Reynolds, D. J., C. A. Richardson, J. D. Scourse, P. G. Butler, A. D. Wanamaker, I. Ridgway, M. D. Sayer, and P. Gulliver. 2013b. The potential of the marine bivalve mollusc Glossus humanus (L.) as a sclerochronological archive. Holocene 23:1711-1720.

Rhodes, M. C., and C. W. Thayer. 1991. Mass extinctions: ecological selectivity and primary production. Geology 19:877-880.

Richards, E. J., and L. R. Leighton. 2012. Size refugia from predation through time: a case-study of two Middle Devonian brachiopod genera. Palaeogeography, Palaeoclimatology, Palaeoecology 363-364:163-171.

Richardson, C. A. 2001. Molluscs as archives of environmental change. Oceanography and Marine Biology 39:103-164.

Richardson, C. A., D. J. Crisp, N. W. Runham, and L. D. Gruffydd. 1980. The use of tidal growth bands in the shell of Cerastoderma edule to measure seasonal growth rates under cool temperate and sub-arctic conditions. Journal of the Marine Biological Association of the United Kingdom 60:977-989.

Ridgway, I. D., C. A. Richardson, and S. N. Austad. 2011a. Maximum shell size, growth rate, and maturation age correlate with longevity in bivalve molluscs. Journals of Gerontology, series A (Biological Sciences and Medical Sciences) 66A:183-190.

Ridgway, I. D., C. A. Richardson, E. Enos, Z. Ungvari, S. N. Austad, E. E. R. Philipp, and A. Csiszar. 2011b. New species longevity record for the northern quahog (=hard clam), Mercenaria mercenaria. Journal of Shellfish Research 30:35-38.

Ropes, J. 1984. Procedures for preparing acetate peels and evidence validating the annual periodicity of growth lines formed in the shells of ocean quahogs, Arctica islandica. Marine Fisheries Review 46:27-35.

Ropes, J. W., F. M. S. D. S. Jones S. A. Murawski, and J. A. Jearld. 1984. Documentation of annual growth lines in ocean quahogs, Arctica islandica Linné. Fishery Bulletin 82:1-19.

Roy, K., D. Jablonski, and J. W. Valentine. 2000. Dissecting latitudinal diversity gradients: functional groups and clades of marine bivalves. Proceedings of the Royal Society of London B 267:293299.

Runnegar, B. 1974. Evolutionary history of the bivalve subclass Anomalodesmata. Journal of Paleontology 48:904-939.

Runnegar, B., and C. Bentley. 1983. Anatomy, ecology and affinities of the Australian Early Cambrian bivalve Pojetaia runnegari Jell. Journal of Paleontology 57:73-92.

Salamon, M. A., P. Gorzelak, R. Niedźwiedzki, D. Trzęsiok, and T. K. Baumiller. 2014. Trends in shell fragmentation as evidence of mid-Paleozoic changes in marine predation. Paleobiology 40:14-23.

Sato, S. 1994. Analysis of the relationship between growth and sexual maturation in Phacosoma japonicum (Bivalvia:Veneridae). Marine Biology 118:663-672.

Sato, S. 1995. Spawning periodicity and shell microgrowth patterns of the venerid bivalve Phacosoma japonicum (Reeve, 1850). The Veliger 38:61-72.

Saulsbury, J., D. K. Moss, L. C. Ivany, M. Kowalewski, D. R. Lindberg, J. F. Gillooly, N. A. Heim, C. R. McClain, J. L. Payne, P. D. Roopnarine, B. R. Schöne, D. Goodwin, and S. Finnegan. 2019. Evaluating the influences of temperature, primary production, and evolutionary history on bivalve growth rates. Paleobiology 45:405-420.
Schöne, B. R., and O. Giere. 2005. Growth increments and stable isotope variation in shells of the deep-sea hydrothermal vent bivalve mollusk Bathymodiolus brevior from the North Fiji Basin, Pacific Ocean. Deep-Sea Research, part I (Oceanographic Research Papers) 52:1896-1910.

Schöne, B., and D. M. Surge. 2012. Part N (revised), vol. 1, chap. 14: bivalve sclerochronology and geochemistry. Treatise Online 46:1-24.

Schöne, B. R., J. Lega, K. W. Flessa, D. H. Goodwin, and D. L. Dettman. 2002. Reconstructing daily temperatures from growth rates of the intertidal bivalve mollusk Chione cortezi (northern Gulf of California, Mexico). Palaeogeography, Palaeoclimatology, Palaeoecology 184:131-146.

Schöne, B. R., E. Dunca, J. Fiebig, and M. Pfeiffer. 2005a. Mutvei's solution: an ideal agent for resolving microgrowth structures of biogenic carbonates. Palaeogeography, Palaeoclimatology, Palaeoecology 228:149-166.

Schöne, B. R., S. D. Houk, A. D. Freyre Castro, J. Fiebig, W. Oschmann, I. Kroncke, W. Dreyer, and F. Gosselck. 2005b. Daily growth rates in shells of Arctica islandica: assessing subseasonal environmental controls on a long-lived bivalve mollusk. Palaios 20:78-92.

Sejr, M. K., and P. B. Christensen. 2007. Growth, production and carbon demand of macrofauna in Young Sound, with special emphasis on the bivalves Hiatella arctica and Mya truncata. Meddelelser om Gronland Bioscience 58:121-135.

Sejr, M. K., M. K. Sand, K. T. Jensen, J. K. Petersen, P. B. Christensen, and S. Rysgaard. 2002. Growth and production of Hiatella arctica (Bivalvia) in a high-Arctic fjord (Young Sound, Northeast Greenland). Marine Ecology Progress Series 244:163-169.

Selin, N. I. 1990. Distribution and growth of the bivalve mollusks Mactra sachalinensis and Mactra chinensis in Peter the Great Bay. Soviet Journal of Marine Biology 3:28-38.

Selin, N. I., and M. S. Selin. 1988. Production characteristics of the bivalve mollusk Callista brevisiphonata in Peter the Great Bay, Sea of Japan. Soviet Journal of Marine Biology 14:219-223.

Sepkoski, D. 2012. Rereading the fossil record: the growth of paleobiology as an evolutionary discipline. University of Chicago Press, Chicago.

Sepúlveda, J., L. Alegret, E. Thomas, E. Haddad, C. Cao, and R. E. Summons. 2019. Stable isotope constraints on marine productivity across the Cretaceous-Paleogene mass extinction. Paleoceanography and Paleoclimatology 34:1195-1217.

Seuß, B., A. Nützel, R. H. Mapes, and T. E. Yancey. 2009. Facies and fauna of the Pennsylvanian Buckhorn Asphalt Quarry deposit: a review and new data on an important Palaeozoic fossil lagerstätte with aragonite preservation. Facies 55:609-645.

Sheehan, P. M., and P. J. Lesperance. 1978. Effect of predation on the population dynamics of a Devonian brachiopod. Journal of Paleontology 52:812-817.

Signor, P. W., and C. E. Brett. 1984. The Mid-Paleozoic precursor to the Mesozoic Marine Revolution. Paleobiology 10:229-245.

Signor, P. W., and G. J. Vermeij. 1994. The plankton and the benthos: origins and early history of an evolving relationship. Paleobiology 20:297-319.

Smith, E. B., K. M. Scott, E. R. Nix, C. Korte, and C. R. Fisher. 2000. Growth and condition of seep mussels (Bathymodiolus childressi) at a Gulf of Mexico brine pool. Ecology 81:2392-2403.

Smith, S. A., C. W. Thayer, and C. E. Brett. 1985. Predation in the Paleozoic: gastropod-like drillholes in Devonian brachiopods. Science 230:1033-1035.

Soldati, A. L., D. E. Jacob, B. R. Schöne, M. M. Bianchi, and A. Hajduk. 2009. Seasonal periodicity of growth and composition in valves of Diplodon chilensis patagonicus (d'Orbigny, 1835). Journal of Molluscan Studies 75:75-85.

Stanley, S. M. 1968. Post-Paleozoic adaptive radiation of infaunal bivalve molluscs. Journal of Paleontology 42:214-229. 
Stearns, S. C. 1992. The evolution of life histories. Oxford University Press, Oxford.

Strahl, J., E. Philipp, T. Brey, K. Broeg, and D. Abele. 2007. Physiological aging in the Icelandic population of the ocean quahog Arctica islandica. Aquatic Biology 1:77-83.

Surge, D., K. C. Lohmann, and D. L. Dettman. 2001. Controls on isotopic chemistry of the American oyster, Crassostrea virginica: implications for growth patterns. Palaeogeography, Palaeoclimatology, Palaeoecology 172:283-296.

Tanabe, K., T. Mimura, T. Miyaji, K. Shirai, K. Kubota, N. MurakamiSugihara, and B. R. Schöne. 2017. Interannual to decadal variability of summer sea surface temperature in the Sea of Okhotsk recorded in the shell growth history of Stimpson's hard clams (Mercenaria stimpsoni). Global and Planetary Change 157:35-47.

Thayer, C. W. 1986. Are brachiopods better than bivalves? Mechanisms of turbidity tolerance and their interaction with feeding in articulates. Paleobiology 12:161-174.

Thomas, J. A., J. J. Welch, R. Lanfear, and L. Bromham. 2010. A generation time effect on the rate of molecular evolution in invertebrates. Molecular Biology and Evolution 27:1173-1180.

Thomas, R. D. K. 1970. Functional morphology, ecology and evolution in the genus Glycymeris (Bivalvia). Ph.D. dissertation. Harvard University, Cambridge, Mass.

Thompson, I., D. S. Jones, and D. Dreibelbis. 1980. Annual internal growth banding and life history of the ocean quahog Arctica islandica (Mollusca: Bivalvia). Marine Biology 57:25-34.

Thorarinsdóttir, G. G., and L. D. Jacobson. 2005. Fishery biology and biological reference points for management of ocean quahogs (Arctica islandica) off Iceland. Fisheries Research 75:97-106.

Tobin, T. S., G. P. Wilson, J. M. Eiler, and J. H. Hartman. 2014. Environmental change across a terrestrial Cretaceous-Paleogene boundary section in eastern Montana, USA, constrained by carbonate clumped isotope paleothermometry. Geology 42:351-354.

Torres, M. E., D. Zima, K. K. Falkner, R. W. Macdonald, M. O'Brien, B. R. Schöne, and T. Siferd. 2011. Hydrographic changes in Nares Strait (Canadian Arctic archipelago) in recent decades based on $\delta^{18} \mathrm{O}$ profiles of bivalve shells. Arctic $64: 45-58$.

Turekian, K. K., J. K. Cochran, D. P. Kharkar, R. M. Cerrato, J. R. Vaisnys, H. L. Sanders, J. F. Grassle, and J. A. Allen. 1975. Slow growth rate of a deep-sea clam determined by ${ }^{228}$ Ra chronology. Proceedings of the National Academy of Sciences USA 72:2829-2832.

Tynan, S., A. Dutton, S. Eggins, and B. Opdyke. 2014. Oxygen isotope records of the Australian flat oyster (Ostrea angasi) as a potential temperature archive. Marine Geology 357:195-209.

Ungvari, Z., D. Sosnowska, J. B. Mason, H. Gruber, S. W. Lee, T. S. Schwartz, M. K. Borwn, N. J. Storm, K. Fortney, J. Sowa, A. B. Byrne, T. Kurz, E. Levy, W. E. Sonntag, S. N. Austad, A. Csiszar, and I. Ridgway. 2013. Resistance to genotoxic stresses in Arctica islandica, the longest living noncolonial animal: is extreme longevity associated with a multistress resistance phenotype? Journals of Gerontology, series A 68:521-529.

Urey, H. C., H. A. Lowenstam, S. Epstein, and C. R. McKinney. 1951. Measurement of paleotemperatures and temperatures of the Upper Cretaceous of England, Denmark, and the Southeastern United States. Bulletin of the Geological Society of America 62:399-416.

Valentine, J. W., and D. Jablonski. 2010. Origins of marine patterns of biodiversity: some correlates and applications. Palaeontology 53:1203-1210.

Van Voorhies, W. A. 2001. Metabolism and lifespan. Experimental Gerontology 36:55-64.

Vermeij, G. J. 1977. The Mesozoic marine revolution: evidence from snails, predators and grazers. Paleobiology 3:245-258.

Vermeij, G. J. 1987. Evolution and escalation. Princeton University Press, Princeton, N.J.

Vermeij, G. J. 2016. Gigantism and its implications for the history of life. PLoS ONE 11(1):e0146092.

Vermeij, G. J., D. E. Schindel, and E. Zipser. 1981. Predation through geological time: evidence from gastropod shell repair. Science 214:1024-1026.

Vilhena, D. A., E. B. Harris, C. T. Bergstrom, M. E. Maliska, P. D. Ward, C. A. Sidor, C. A. E. Strömberg, and G. P. Wilson. 2013. Bivalve network reveals latitudinal selectivity gradient at the end-Cretaceous mass extinction. Scientific Reports 3:1-5.

Walliser, E. O., B. R. Schöne, T. Tutken, J. Zirkel, K. I. Grimm, and J. Pross. 2015. The bivalve Glycymeris planicostalis as a highresolution paleoclimate archive for the Rupelian (Early Oligocne) of central Europe. Climate of the Past 11:653-668.

Wells, J. W. 1963. Coral growth and geochronometry. Nature 197:948-950.

Westerheim, S. J., and W. E. Ricker. 1978. Bias in using an age-length key to estimate age-frequency distributions. Journal of the Fisheries Research Board of Canada 35:184-189.

Weymouth, F. W. 1923. The life-history and growth of the Pismo clam (Tivela stultorum Mawe). Fishery Bulletin of California 7.

Williams, D. F., M. A. Arthur, D. S. Jones, and N. Healy-Williams. 1982. Seasonality and mean annual sea surface temperatures from isotopic and sclerochronological records. Nature 296:432434.

Yancey, T. E., and K. Ozaki. 1986. Redescription of the genus Shikamaia, and clarification of the hinge characters of the family Alatoconchidae (Bivalvia). Journal of Paleontology 60:116-125

Yavnov, S. V., and A. V. Ignat'ev. 1979. Shell structure and growth temperature of mollusks, Family Mactridae. Biologiya Morya 5:44-48.

Zolotarev, V. N. 1980. The life span of bivalves from the Sea of Japan and Sea of Okhotsk. Soviet Journal of Marine Biology 6:301-308. 